\title{
Uluslararası İlişkiler ve Uluslararası Göç Bağlamında İnsan Ticareti
}

\author{
Human Trafficking in the Context of \\ International Relations and International Migration
}

Cilt: 15

Sayı: 30

Fulya MEMIŞOĞLU*

$\ddot{O} z$

Uluslararası boyutta insan ticareti, dünya genelinde artan karma göç hareketlerinin de etkisiyle 21. yüzyllın en önemli küresel sorunlarından biri haline gelmiştir. Insan ticaretiyle mücadele son ylllarda hükümetler, uluslararası kuruluşlar, sivil toplum örgütleri ve medyanın yoğun ilgi gösterdiği bir alandır, ancak bu durum zaman zaman kavramı teorik ve olgusal bulgularla anlamaya çalışan akademik tartı̧̧maların önüne geçmektedir. Bu çalışmanın temel amacı insan ticareti konusunda uluslararası ilişkiler ve uluslararası göç literatürüne bağlantılı olarak süregelen başlıca kavramsal mevzular ve teorik tartışmalara yer vermek; soruna yönelik etkin mücadele stratejileri geliştirmek için öncelikle bu hususların göz önünde bulundurulmass gerektiğini vurgulamaktır. Çalışmanın birinci bölümü̈de insan ticareti, göçmen kaçakçıllı̆̆ ve düzensiz göç gibi temel kavramlar arasındaki bağlantı ele alınacaktır. İkinci bölümde ise insan ticaretinin göç ve güvenlik olguları bağlamında kuramlaştırlmasına değinilecektir. Çalısmanın son bölümünde Türkiye'de göç politikaları kapsamında gerçekleşen kurumsal ve hukuki yapılandırma sürecinin insan ticaretiyle mücadelenin de mağdur odaklı bir çerçevede geliştirilmesine katkısı değerlendirilecektir.

Anahtar Kelimeler: Insan Ticareti, Göçmen Kaçakçıllı̆̆ı, Uluslararası Göç, Türkiye, İnsan Güvenliği.

* Dr. Öğr. Üyesi, İstanbul Yıldız Teknik Üniversitesi, e-posta: fulyam@ yildiz.edu.tr.

Geliș Tarihi/Arrived: 24.01.2019

Kabul Tarihi/Accepted: 19.04.2019 


\section{Abstract}

With increased and diversified mixed migration flows across the world, international human trafficking has become one of the most critical global challenges of the 21st century. The growing interest in the "global fight against human trafficking" rhetoric at times overshadows academic debates that provide an understanding of the concept based on factual/theoretical evidence. Main objective of this study is to overview the main conceptual and theoretical debates within the scope of international relations and international migration in an attempt to emphasise their significance in developing effective anti-trafficking strategies. Among other issues, the first part of the paper examines the conceptual relationship between human trafficking, migrant smuggling, and irregular migration. The second part addresses theoretical debates on human trafficking with reference to migration and security phenomena. The final part of the paper assesses the contribution of Turkey's newly reformed migration institutional and legal framework on the development of a victim-oriented anti-trafficking policy in line with international standards.

Keywords: Human Trafficking (Trafficking in Persons, Trafficking in Human Beings), Migrant Smuggling, International Migration, Turkey, Human Security.

\section{Giriş}

İnsan ticareti (human trafficking, trafficking in persons, trafficking in human beings), dünya genelinde giderek artan ve çeşitlenen karma göç hareketlerinin de etkisiyle 21. yüzyılın en önemli küresel sorunlarından biri haline gelmiştir. ${ }^{1}$ Günümüzde modern kölelik, insan hakkı ihlali, düzensiz göç sorunu, sınıraşan organize suç türü, ulusal egemenlik ve güvenlik için tehdit unsuru gibi çeşitli şekillerde tasvir edilen insan ticareti, bütün bu öğeleri birleştiren bir durumu da ifade edebilmektedir. İnsan ticareti kapsamında değerlendirilen suçlar arasında bir kimsenin kandırılarak ya da zor kullanılarak çalıştırılması, hizmet

1 İnsan ticareti hem ülke içinde, hem de ülkeler arasında gerçekleşmektedir. Bu çalışma insan ticaretinin uluslararası boyutuna odaklanmaktadır. 
Uluslararası İlişkiler ve Uluslararası Göç Bağlamında İnsan Ticareti

ettirilmesi, fuhuş ya da diğer cinsel amaçlarla istismar edilmesi, organ ve dokularından istifade edilmesi gibi onur kırıcı muamelelere maruz kalması yer almaktadır. ${ }^{2}$ Zorla dilendirme, yasadışı evlat edinme, erken yaşta ve zorla yapılan evlilikler, çocukların suçta, silahlı çatışmada veya asker olarak kullanımı gibi geniş bir yelpazede insan ticareti suçu işlenmektedir. ${ }^{3}$

İnsan ticaretinin nedenleri bölgeden bölgeye ülkeden ülkeye farklılıklar gösterebilmektedir. Uluslararası bağlamda ise ekonomik darlıklar, sosyal ve kültürel unsurlar, siyasi istikrasızlık ve suç örgütlerinin rolü insan ticaretini tetikleyen ortak faktörler arasında gösterilmektedir. ${ }^{4}$ Savaş, iç çatışmalar, doğal afetler insan ticaretinde artışa yol açabilirken, bu gibi durumların neden olduğu yerinden edilme ve zorunlu göç hareketlerinden etkilenen bireyler, insan ticareti yoluyla istismara nispeten daha hassas hale gelebilmektedir. ${ }^{5}$ Insan ticareti ulusal sinırlar içerisinde de gerçekleşmektedir, ancak uluslararası arenada daha ön plana çıkan konunun göç ve güvenlik olgularıyla yakından ilintili olan ulusaşırı boyutudur. Çalışmanın ilerleyen bölümlerinde daha detaylı ele alınacağı üzere, bu duruma zemin hazırlayan başlıca faktörler kısaca aşağıdaki gibi özetlenebilir.

Öncelikle, Soğuk Savaş sonrasında hızla değişen yapılar ve koşullar sonucunda devletler güvenlik tanımlamalarını yeniden inşa etmiş ve bu doğrultuda devlet dişı olaylar da güvenlik meselesi haline gelmiştir. Bunlardan biri de, düzensiz göçtür. İnsan ticaretinin düzensiz göçün bir türevi olarak görülmesi de konuya yönelik küresel ilginin artmasına yol

\footnotetext{
${ }^{2}$ United Nations Office on Drugs and Crime (UNODC), "Human Trafficking", 2018, https://www.unodc.org/unodc/en/human-trafficking/what-is-human-trafficking.html (Erişim Tarihi: 01.12. 2018).

${ }^{3}$ Agy.

4 Kevin Bales, "What Predicts Human Trafficking?", International Journal of Comparative and Applied Criminal Justice, 31(2), 2007, s. 269-279.

${ }^{5}$ Agm, s.270; Claire Healy, Targeting Vulnerabilities: The Impact of the Syrian War and Refugee Situation on Trafficking in Persons, International Centre for Migration Policy Development (ICMPD), 2015, https://www.icmpd.org/fileadmin/ICMPD-Website/ AntiTrafficking/Targeting_Vulnerabilities_EN_SOFT_.pdf (Erişim Tarihi: 01.12.2018)
}

\section{1}

Güvenlik Stratejileri

Cilt: 15

Say1: 30 
açmıştır. Artan ilgiyle birlikte, insan ticaretine karş1 mücadelede uluslararası iş birliği vurgusu küresel politika gündeminde gittikçe önem

Güvenlik Stratejileri

Cilt: 15

Say1: 30 kazanmaktadır. Nitekim Birleşmiş Milletler (BM) 2030 Sürdürülebilir Kalkınma Gündemi kapsamında modern köleliği ve insan ticaretini sona erdirmek, zorla çalıştırmayı ortadan kaldırmak, çocukların askere alınmaları ile asker olarak kullanılmaları da dâhil olmak üzere çocuk işçiliğinin en kötü türlerinin yasaklanmasını ve ortadan kaldırılmasını güvence altına almak için acil ve etkili önlemler alınması ve 2025 'e kadar çocuk işçiliğinin her türünün sona erdirilmesine yönelik hedefler (Hedef 8 ve Hedef 16) yer almaktadır. ${ }^{6}$ Küresel Göç Mutabakatı ise, BM'nin hükümetlerarası müzakereler neticesinde uluslararası göç alanında iş birliğini geliştirmek amacıyla kabul ettiği ilk belgedir. Belgede önerilen 22 genel hedeften biri insan ticaretinin önlenmesi ve insan ticaretiyle mücadele edilmesi yönündedir. ${ }^{7}$

İnsan ticareti, toplumsal cinsiyetten kriminolojiye kadar farklı çalışma alanlarında çok sayıda bilimsel araştırmaya, akademik tartışmalara ve savunuculuk faaliyetlerine konu olmaktadır. Konunun kamuoyu ve politika gündemine yansımalarında ise birtakım tutarsızlıklar göze çarpmaktadır. Bir taraftan mücadelenin önemini vurgulamak amaciyla "insan ticareti modern köleliktir" gibi sloganlar sıkça gündeme gelmektedir. ${ }^{8}$ Diğer taraftan ise insan ticaretiyle ilgili yaygın fakat yanlış olan bilgiler, kanıta dayalı olmayan veriler sebebiyle aslında tam olarak ne ile mücadele edildiği ve nasıl mücadele edilmesi

6 Birleşmiş Milletler Uluslararası Kalkınma Programı (United Nations Development Programme/UNDP), "2030 Sürdürülebilir Kalkınma Hedefleri”, 2018, http://www.tr.undp. org/content/turkey/tr/home/sustainable-development-goals.html (Erișim Tarihi: 01.12.2018).

${ }^{7}$ BM Küresel Göç Mutabakatı (UN Global Compact for Migration), "Global Compact for Safe, Orderly and Regular Migration, Intergovernmentally Negotiated and Agreed Outcome", 2018, https://refugeesmigrants.un.org/sites/default/files/180711_final_draft _0.pdf (Erişim Tarihi: 01.12.2018)

${ }^{8}$ Natalie Jesionka, "Human Trafficking: The Myths and the Realities", The Daily Muse, 2019, https://www.themuse.com/advice/human-trafficking-the-myths-and-the-realities (Erişim Tarihi: 12.03.2019). 
gerektiği bilinmemektedir. ${ }^{9}$ Öncelikle dünya genelinde insan ticaretinin ne büyüklükte olduğu ve toplam ne kadar insanı etkilediğine dair güvenilir ve sistematik bütünleşik bir bilgi kaynağı bulunmamaktadır. ${ }^{10}$ Dolayısıyla yapılan değerlendirmeler genelde tahminlere dayanmaktadır. Gizli doğası ve mağdurların tespitinde karşılaşılan çeşitli zorluklar nedeniyle, resmî rakamların da insan ticaretini yalnızca asgari oranda yansıttığı kabul edilmektedir. ${ }^{11} \mathrm{Bu}$ da insan ticaretiyle mücadele retoriğinin zaman zaman anlamını yitirmesine yol açmakta ve etkin mücadele stratejileri geliştirilmesini zorlaştırmaktadır. Aşağıda değinileceği üzere, insan ticareti üzerine yapılan küresel tahminler ile yetkililerce tespit edilen mağdur sayıları arasındaki çarpıcı uçurum aslında ne denli az sayıda kişinin koruma mekanizmalarına erişimi olduğunu göstermektedir.

Uluslararası Çalışma Örgütü'nce (International Labour Organization-ILO) 2017 'de yayınlanan "Modern Kölelik üzerine Küresel Tahminler Raporu"nda dünya genelinde yaklaşık 25 milyon kişinin zorla çalıştırıldığı, 15 milyon kişinin ise zorla evlendirildiği, böylece 40 milyonu aşan bir nüfusun modern kölelik mağduru olduğu ifade edilmektedir. ${ }^{12}$ Buna karşılık, Birleşmiş Milletler Uyuşturucu ve Suç Ofisi (United Nations Office On Drugs and Crime-UNODC) tarafindan resmî verilere dayanarak hazırlanan "2016 Küresel İnsan Ticareti Raporu"na göre 106 ülkede tespit edilen ve resmî kurumlarca insan ticareti mağduru olarak tanımlanan toplam kişi sayısı 63.251'le sınırlı kalmıştır. ${ }^{13}$ Raporda yer alan diğer veriler ise uluslararası sistemde devletlerin çoğunluğunun sınıraşan insan ticareti akışlarından etkilendiğini

\footnotetext{
${ }^{9}$ İnsan ticaretinin göçmen kaçakçılığı ile eşdeğer görülmesi, insan ticaretinin sadece ülkeler arasında gerçekleştiği algısı, insan ticaretinin sadece cinsel istismar amaçlı meydana gelmesi ve mağdurların yalnızca kadınlardan oluştuğu bu tür yaygın bilinen yanlış bilgilere örnek olarak gösterilebilir. Daha detaylı bir analiz için bkz. Agy.

${ }^{10}$ International Labour Organization (ILO), "Global Estimates of Modern Slavery: Forced Labour and Forced Marriage”, 2017, https://www.ilo.org/wcmsp5/groups/public/ --dgreports/---dcomm/documents/publication/wcms_575479.pdf (Erişim Tarihi: 01.12.2018). ${ }^{11}$ Agy, s.1.

12 "Global Estimates of Modern Slavery: Forced Labour and Forced Marriage", a.g.y., s. 9.

13 "UN Global Report on Trafficking in Persons 2016", a.g.y., s. 23.
}

\section{3}

Güvenlik Stratejileri

Cilt: 15

Say1: 30 
göstermektedir. Dünya genelinde 500'den fazla farkl1 insan ticareti akışının gerçekleştiği; tespit edilen insan ticareti mağdurların \%42'sinin ülke içindeki mağdurlardan oluştuğu ve sadece Batı ve Güney Avrupa'da tespit edilen insan ticareti mağdurlarının 137 farklı menşe ülkeden geldiği belirtilmektedir. ${ }^{14}$

Son yıllarda hükümetler, uluslararası kuruluşlar, sivil toplum kuruluşları, kamuoyu ve medyanın insan ticaretiyle mücadele konusuna gösterdiği yoğun ilgi, zaman zaman bu kavramı teorik ve olgusal kanıtlarla anlamaya çalışan tartışmaların da önüne geçmektedir. Örneğin, akademik çalışmalarda sıkça dile getirilen temel bir eleştiri, insan ticaretine yönelik küresel verilere ulaşmada kullanılan kavramsal tanımların ve araştırma yöntemlerinin kısıtlayıcı olmasının bu verileri yetersiz ve tutarsız kılabilmesidir. ${ }^{15}$ Buna bağlı olarak, insan ticareti gibi geniş kapsamlı ve ölçülemeyen bir konuya ilişkin hukuki tanımlar yapmanın insan ticaretinin daha az tespit edilen türlerinin etkin bir şekilde irdelenmesine engel olabildiği ve hukuki tanımlar dışında kalan hassasiyetlerin göz ardı edilebildiği yönündedir. Diğer taraftan, insan ticaretinin bir devlet güvenliği sorunu olarak $\mathrm{m}$ yoksa insan güvenliğini tehdit eden bir olgu olarak mı kuramlaştırılması gerektiği öne çıkan tartışmalar arasındadır.

$\mathrm{Bu}$ çalışmanın genel amacı insan ticareti konusunda uluslararası ilişkiler ve uluslararası göç literatürüne bağlantılı olarak süregelen başlıca kavramsal mevzular ve teorik tartışmalara yer vermek; etkin mücadele stratejileri geliştirilmesinde bu hususların dikkate alınması gerektiğini vurgulamaktır. Bu bağlamda insan ticaretinin insan güvenliği

14 “UN Global Report on Trafficking in Persons 2016”, UNODC Publication, Vienna, 2016, s. 5. https://www.unodc.org/documents/data-and-analysis/glotip/2016_Global_ Report_on_Trafficking_in_Persons.pdf (Erişim Tarihi: 01.12.2018).

${ }^{15}$ Kavramsal tartışmalar üzerine kapsamlı çalışmalar için bkz. Liz Kelly, "You Can Find Anything You Want: A Critical Reflection on Research on Trafficking in Persons within and into Europe", International Migration, 2005, Cilt 43, No 1/2, s.235-265; Mary Crawford, Sex Trafficking in South Asia: Telling Maya's Story, Routledge, New York, 2010; Leah E. Daigle ve Lisa R. Muftic, Victimology, Sage Publications, USA, 2016. 
odaklı bir yaklaşımla kavramsallaştırılması ve kuramlaştırılması çalışmanın temel argümanını oluşturmaktadır. Böylece hem insan ticareti mağdurlarına yönelik daha kapsamlı bir koruma çerçevesi geliştirilebilir, hem de devletlerin bu alanda etkin iş birliği mekanizmaları oluşturmalarına katkı sağlanabilir. Çalışmada Türkiye örneği üzerinden değerlendirileceği üzere, göç politikalarının insan güvenliğini esas alan bir yaklaşımla ele alınması, insan ticaretiyle mücadele alanının da bu doğrultuda geliştirilmesine firsat vermektedir. Nitekim Türkiye'de göç yönetimi kapsamında son yıllarda yapılan kurumsal ve hukuki düzenlemeler sonucunda yetkililerce tespit edilen insan ticareti mağdur sayısında özellikle 2013 yılından itibaren artış kaydedildiği, mağdurların korunmasına yönelik hizmetlerin geliştiği, farkındalık çalışmalarının yoğunlaştı̆̆ 1 , ulusal ve uluslararası koordinasyon mekanizmalarının güçlendiği gözlenmektedir. ${ }^{16}$

Çalı̧̧manın birinci bölümünde insan ticareti, göçmen kaçakçılığ 1 ve düzensiz göç gibi temel kavramlar ve aralarındaki bağlantı ele alınacak; ikinci bölümde ise teorik tartışmalar çerçevesinde insan ticaretinin güvenlik ve göç olguları bağlamında kuramlaştırılmasına değinilecektir. Çalışmanın son bölümünde Türkiye'de insan ticaretiyle mücadele alanında yapılan güncel düzenlemelerden bahsedilecek; göç politikaları kapsamında gerçekleşen kurumsal ve hukuki yapılandırma sürecinin insan ticaretine karşı etkin bir koruma çerçevesi geliştirilmesine katkısı değerlendirilecektir. $\mathrm{Bu}$ değerlendirmeyi nitel verilerle desteklemek amacıyla Türkiye'de insan ticaretiyle mücadele alanında uzman beş kişiyle Aralık 2017'de gerçekleştirilen derinlemesine mülakatlardan bulgulara yer verilecektir. ${ }^{17}$ Yarı yapılandırılmış derinlemesine

\footnotetext{
16 İnsan ticareti ve diğer ulusal göç istatistikleri için bkz. Göç İdaresi Genel Müdürlüğü (GİGM) Resmî İnternet Sayfas1, "Göç İstatistikleri: İnsan Ticareti”, http://www.goc.gov.tr/ icerik6/insan-ticareti-ile-mucadele_363_378_4714_icerik (Erişim Tarihi: 27.12. 2018).

${ }^{17}$ Bahsedilen mülakatlar yazarın insan ticareti alanında toplam 35 uzmanla gerçekleştirdiği derinlemesine mülakatların bir parçasını oluşturmaktadır. Bu nitel araştırmanın verileri yazarın hazırlamakta olduğu "Unpacking Turkey's Anti-trafficking Policy and Strategies" [Türkiye'nin İnsan Ticaretiyle Mücadele Politika ve Stratejilerinin Analizi] başlıklı makalesinde kapsamlı bir şekilde analiz edilmektedir. Mülakat gerçekleştirilen uzmanlara
}

\section{5}

Güvenlik Stratejileri

Cilt: 15

Say1: 30 
mülakatların amacı insan ticareti alanında politika oluşturma, geliştirme ve uygulama süreçlerinde aktif olarak yer alan kamu kurumu, uluslararası

Güvenlik Stratejileri

Cilt: 15

Sayı: 30 kuruluşlar ve sivil toplum örgütü temsilcilerinin konuya bireysel bakış açılarını anlamak ve değerlendirmektir. Bulgularda ortak noktalar birleştirilerek analiz edilmiştir.

\section{1. İnsan Ticareti Üzerine Kavramsal Tartışmalar}

İnsan ticareti alanında kavramsal tartışmalar ilk olarak 20. yüzyılın başlarından itibaren özellikle Avrupalı ve Amerikalı kadın ve kızların cinsel amaçlı istismarı ile özdeşleştirilen beyaz köle ticareti (white slave trade) kapsamında ele alınmıştır. ${ }^{18} 1980$ 'lere kadar insan ticaretiyle mücadele sınırlı sayıda sivil toplum kuruluşunun düşük bütçelerle ve yoğunlukla kadınları içeren cinsel istismar boyutu üzerinde odaklandığı bir alan olarak kalmıştır. ${ }^{19}$ Makei’ye göre, Soğuk Savaş dönemi boyunca insan ticaretine yeteri kadar ilgi gösterilmemesi, ideolojik kutuplaşmalar sonucu uluslararası göç hareketlerinin nispeten bu bloklar çerçevesinde gerçekleşmesi ve devletlerin sınır ötesi ortak sorunlardan ziyade geleneksel güvenlik konularına eğilmiş olmasından kaynaklanmaktadır. ${ }^{20}$ 1990'ların başından itibaren ise insan ticareti yeni rotalarda, farklı istismar türleri ve mağdur profilleri içeren bir biçimde sürekli olarak

mülakat kodlamasında anonim, kişi adı, kurum adı, görev/unvan gibi seçeneklerden hangisini tercih ettikleri sorulmuştur; kodlamalar bu tercihe göre yapılmıştır.

18 İnsanların kölelik kapsamında ticaretinin tarihsel gelişimi ve günümüze etkilerinin kapsamlı değerlendirmesi için bkz. Annuska Derks, Combating Trafficking in South East Asia, A Review of Policy and Programme Responses, International Organization for Migration, Geneva, 2000; John T. Picarelli, "Historical Approaches to the Trade in Human Beings”, Maggy Lee, (ed.), Human Trafficking, Routledge, New York, 2007, ss. 40-62.

${ }^{19}$ Diana Wong, "The rumor of trafficking: border controls, illegal migration, and the sovereignty of the nation-state", W. van Schendel ve I. Abraham, (ed.), Illicit Flows and Criminal Things: States, Borders, and the Other Side of Globalization, Indiana University Press, Bloomington, 2005, s. 69.

${ }^{20}$ Vladimir Makei, "Human Trafficking in the Post-Cold War Period: Towards a More Comprehensive Approach", Columbia University Journal of International Affairs, 2013, http://jia.sipa.columbia.edu/online-articles/human-trafficking-post-cold-war/ (Erişim Tarihi: 01.12. 2018). 
Uluslararası İlişkiler ve Uluslararası Göç Bağlamında İnsan Ticareti

artmaya devam etmiştir. ${ }^{21}$ Böylece insan ticaretinin çok yönlü boyutlarının uluslararası alanda sistematik olarak irdelenmesi ancak 20. yüzyılın sonlarına doğru ivme kazanmıştır. Örneğin, Shelley, bu dönemin kapsamlı bir analizini Sovyetler Birliği’nin dağılma süreciyle gerçekleşen sosyal ve ekonomik çöküşün özellikle Orta Asya ve Doğu Avrupa'da milyonlarca kişiyi işsizlik, yerinden edilme ve benzeri durumlarla karşı karşıya bırakarak, istismara açık hale getirmesi üzerinden incelemektedir. ${ }^{22}$ Yazar kısa sürede gelişen suç örgütü ağları vasıtasıyla bölgedeki ülkelerin Batı Avrupa'dan Doğu Asya'ya kadar geniş bir coğrafyaya yayılan insan ticareti akışlarında kaynak, transit ve hedef konumuna geldiğini vurgulamaktadır. ${ }^{23}$

$\mathrm{Bu}$ süreçte insan ticareti ve aynı şekilde ön plana çıkan göçmen kaçakçılığı, uluslararası göçün düzensiz ve yasadışı birer türevi olarak kabul görmeye başlamış ve ortak bir uluslararası politika sorununa dönüşmüştür. ${ }^{24}$ Ancak 1990'lar boyunca insan ticareti, göçmen kaçakçılığg ve yasadışı göç çoğunlukla eşdeğer durumları ifade etmek için kullanılmış, bu kavramları birbirinden ayıran farklar üzerinden uluslararası bir görüş birliğine varılamamıştır. ${ }^{25}$ Insan ticaretinin istismar içeren bir olgu olduğu ve bu nedenle mağdurların korunması ve suçluların cezalandırılması için daha kapsamlı bir mücadele gerektiği ise ancak 2000'li yıllardan itibaren kabul görmeye başlamış; başta BM, Avrupa Konseyi, Avrupa Birliği (AB) ve Amerika Birleşik Devletleri'nde (ABD'de) olmak üzere uluslararası, bölgesel ve ulusal hukuki düzenlemelerin yapılmasına yol açmıştır. ${ }^{26}$ Nitekim 2000 yılında BM

\footnotetext{
${ }^{21}$ Alison Brysk ve Austin Choi-Fitzpatrick, From Human Trafficking to Human Rights: Reframing Contemporary Slavery, University of Pennsylvania Press, Philadelphia, 2012, s. 20.

${ }^{22}$ Louise Shelley, Human Trafficking, A Global Perspective, Cambridge University Press, Cambridge, 2010.

${ }^{23}$ A.g.e., s. 174.

${ }^{24}$ Liz Kelly, a.g.m., ss. 236-7.

25 Andrea Di Nicola, "Researching int Human Trafficking: Issues and Problems", Maggy Lee (ed.), a.g.e, s. 63.

${ }^{26}$ Diana Wong, a.g.e., s. 70.
}

\section{7}

Güvenlik Stratejileri

Cilt: 15

Sayı: 30 
tarafindan kabul edilen ve 2003 yılında yürürlüğe giren "Sınıraşan Örgütlü Suçlara Karşı BM Sözleşmesi”ne ek protokollerle, insan ticareti ve göçmen kaçakçılığı, iki ayrı suç kategorisi olarak ele alınmış ve uluslararası ölçekte tanımları netlik kazanmıştır. "İnsan Ticaretine İlişkin Ek Protokol"ün insan ticareti suçunu açıklayan 3. Maddesi aşağıda aynen aktarılmıştır:

“(a) Insan ticareti kuvvet kullanarak veya kuvvet kullanma tehdidi ile veya diğer bir biçimde zorlama, kaçırma, hile, aldatma, nüfuzu kötüye kullanma, kişinin çaresizliğinden yararlanma veya başkası üzerinde denetim yetkisi olan kişilerin rızasını kazanmak için o kişiye veya başkalarına kazanç veya çıkar sağlama yoluyla kişilerin istismar amaçlı temini, bir yerden bir yere taşınmasi, devredilmesi, barındırılması veya teslim alınması anlamina gelir. İstismar terimi, asgari olarak, başkalarının fuhuşunun istismar edilmesini veya cinsel istismarın başka biçimlerini, zorla çalıştırmayı veya hizmet ettirmeyi, esareti veya esaret benzeri uygulamaları, kulluğu veya organların alınmasın içermektedir.

(b) Insan ticaretinin (a) bendinde belirtilen yöntemlerden herhangi biriyle yapılmış olması mağdurun bu istismara razı olup olmaması durumu değiştirmeyecektir.

(c) Bu maddenin (a) bendinde öngörülen yöntemlerden herhangi birini içermese bile, çocuğun istismar amaçlı temini, bir yerden bir yere taşınmasl, devredilmesi, barındırılması veya teslim alınması insan ticareti olarak kabul edilecektir.

(d) On sekiz yaşının altındaki herkes çocuk kabul edilecektir." 27

$\mathrm{Bu}$ çerçevede İnsan Ticaretine ilişkin Ek Protokol, insan ticaretini üç temel öğe (eylemler, araçlar, amaçlar) içermesi temelinde tanımlamaktadır (Bkz. Tablo 1). Protokol uyarınca, kadın ve çocuklara özel önem verilerek insan ticaretini önlemek ve mücadele etmek; insan

${ }^{27}$ Sinırıaşan Örgütlü Suçlarla Mücadele Sözleşmesine ek Insan Ticaretinin, Özellikle Kadın ve Çocuk Ticaretinin Önlenmesine, Durdurulmasına ve Cezalandırllmasına İlişkin Protokol, Viyana, Birleşmiş Milletler, Aralık, 2000. 
ticareti mağdurlarının insan haklarına bütünüyle saygı göstererek onları korumak ve yardım etmek; taraf devletler arasında iş birliğini geliştirmek amaçlanmaktadır. 4P (prevention, protection, prosecution, partnership [önleme, koruma, kovuşturma, iş birliği]) olarak bilinen bu yaklaşım daha sonraki yıllarda UNODC tarafindan devletlere "Eylem Çerçevesi" ismi altında protokolün etkili olarak uygulanmasında teknik bir araç olarak sunulmuştur. ${ }^{28}$ İlerleyen bölümlerde Türkiye örneği üzerinden değinileceği gibi, 4P yaklaşımı insan ticaretiyle mücadelede mağdur-odaklı politika geliştirilebilmesi için devletlere bir yol haritası sunmaktadır.

\section{Tablo 1: BM İnsan Ticaretine iliş kin Ek Protokol Kapsamında İnsan Ticaretini Tanımlayan Temel Unsurlar.}

\begin{tabular}{|c|c|c|}
\hline EYLEM & ARAÇLAR & AMAÇ (asgari olarak) \\
\hline $\begin{array}{c}\text { Kişileri istismar } \\
\text { amaçl temin etmek }\end{array}$ & Kuvvet kullanma & $\begin{array}{c}\text { Zorla çalıştırma } \\
\text { veya hizmet ettirme }\end{array}$ \\
\hline $\begin{array}{c}\text { Bir yerden bir yere } \\
\text { taşımak }\end{array}$ & Kuvvet kullanma tehdidi & $\begin{array}{l}\text { Fuhuş amaçlı ve diğer } \\
\text { amaçlı cinsel istismar }\end{array}$ \\
\hline Devretmek & Diğer biçimlerde zorlama & $\begin{array}{c}\text { Esaret ve esaret } \\
\text { benzeri uygulamalar }\end{array}$ \\
\hline Barındırmak & Kaçırma & Kulluk \\
\hline Teslim almak & Hile ve aldatma & Organların alınması \\
\hline \multicolumn{3}{|c|}{ Kişinin çaresizliğinden yararlanma } \\
\hline & $\begin{array}{l}\text { Kişinin rızasını kazanmak için o } \\
\text { kişiye veya başkalarına kazanç } \\
\text { ve çıar sağlama }\end{array}$ & \\
\hline
\end{tabular}

Kaynak: Yazar tarafindan Sınıraşan Örgütlü Suçlara Karşı Birleşmiş Milletler Sözleşmesi İnsan Ticaretine İlişkin Ek Protokolü’nden uyarlanmıştır. Bkz., Sinırıaşan Örgütlü Suçlarla Mücadele Sözleşmesine ek İnsan Ticaretinin, Özellikle Kadın ve Çocuk Ticaretinin Önlenmesine, Durdurulmasina ve Cezalandirllmasına İlişkin Protokol, Viyana, Birleşmiş Milletler, Aralık, 2000.

28 "International Framework for Action to Implement the Trafficking in Persons Protocol", UNODC, Vienna, 2009, https://www.unodc.org/documents/human-trafficking/ Framework _for_Action_TIP.pdf (Erişim Tarihi: 01.12.2018). 
250

Güvenlik Stratejileri

Cilt: 15

Sayı: 30

Konuyla mücadelenin insan hakları ve toplumsal cinsiyet eşitliği temelinde gelişmesi gerektiği ve bu bağlamda devletlerin insan ticareti mağdurlarını etkin şekilde tespit etme ve koruma yükümlülüğü bulunduğu, 2005'te imzalanan ve 2008'de yürürlüğe giren "Avrupa Konseyi İnsan Ticaretine Karşı Eylem Sözleşmesi”yle daha da önem kazanmıştır. ${ }^{29}$ Ancak uluslararası hukuk alanında insan ticaretinin tanımlanmasıyla kavramsal tartışmalar son bulmamıştır. Giriş kısmında da belirtildiği gibi, bu tartışmalardan temel bir tanesi resmî rakamlara yönelik eleştiriler olmak üzere genel anlamda insan ticaretini küresel anlamda ölçmenin zorluklarına ilişkindir. İnsan ticaretiyle ilgili sayısal verilere özellikle devlet kanalları aracılığıyla erişim son yıllarda nispeten iyileşmişse de, hem ulusal istatistiklerin hem de küresel verilerin daha ziyade tahminler üzerinden olduğu vurgulanmaktadır. ${ }^{30} \mathrm{Az}$ sayıda ülkenin insan ticaretiyle ilgili sistematik veri toplamas1, ulusal mevzuatlarda insan ticareti tanımlarının birbirinden farklılık göstermesi, bölgelerarası karş1laştırabilir verilerin yetersizliğine neden olmakta ve böylece insan ticaretinin küresel anlamda kavramsallaştırılmasına engel olmaktadır. ${ }^{31}$ Başka bir deyişle, ölçeği tam olarak bilinemeyen bir olgunun nasıl tanımlanması gerektiği konusunda görüş ayrılıkları bulunmaktadır. İkinci ve bununla ilgili bir başka mevzu ise insan ticareti gibi geniş kapsamlı ve ölçülemeyen bir konu üzerinde hukuki tanımlar yapmanın insan ticaretinin zorla çalıştırılma, zorla dilendirilme gibi daha az tespit edilen biçimlerinin araştırmacılar tarafından etkin bir şekilde irdelenemediği yönündedir. Medyada, uluslararası ve ulusal politika tartışmalarında ve akademik çalışmalarda özellikle de bu kısıtlayıcı hukuki tanımlar nedeniyle en büyük ilgiyi insan ticaretinin daha görünebilir olan kadın ve genç kızların ticaret amaçlı cinsel istismar boyutunun çektiği öne sürülmektedir. ${ }^{32}$ UNODC 2016 Küresel İnsan Ticareti Raporu'nda

${ }^{29}$ Convention on Action against Trafficking in Human Beings, Warsaw, Council of Europe, 16 Mayis 2005.

${ }^{30}$ Frank Laczko, "Introduction, Data and Research on Human Trafficking: A Global Survey", International Migration, 2005, Cilt 43, No 1/2, s. 5.

${ }^{31}$ Agm, ss. 5-7.

${ }^{32}$ Andrea Di Nicola, age, ss. 65-7. 
yer alan veriler ise bu durumu doğrular niteliktedir, ancak geçtiğimiz on y1l içerisinde değişen göstergelere de işaret etmektedir. Nitekim uluslararası düzeyde tespit edilen mağdurların $\% 79$ gibi yüksek bir oranını hâlâ kadın ve çocuklar oluşturmasına rağmen, özellikle zorla çalıştırılan erkek mağdur sayısında da artış yaşanmıştır. ${ }^{33}$ Bununla birlikte, cinsel istismar amaçlı sömürü hâlen en çok tespit edilen insan ticareti türü olsa da, 2012-2014 yılları arasında tespit edilen her 10 mağdurdan dördünün zorla çalıştırma mağduru olduğu ve toplam rakamın \%63'ünün erkek mağdurlardan oluştuğu saptanmıştır. ${ }^{34}$

Literatürde dikkat çeken ayrı bir kavramsal tartışma alanı İnsan Ticaretine ilişkin ek Protokol'de "başkalarının fuhşunun istismar edilmesini veya cinsel istismarın başka biçimlerini" içeren eylemlerin insan ticareti kapsamında nasıl değerlendirilmesi gerektiğine ilişkindir. Fuhuş sektöründe kişinin kendi isteği ve rızasıyla çalışabilme hakkı açısından fuhşun yasaklanması yerine yasallaştırılması gerektiğini savunan çevreler seks işçiliği kavramının zorunlu fuhuş tanımından ayrı tutulması gerektiğini ifade ederler. ${ }^{35}$ Ancak seks işçiliğinde de tercih ve rıza kavramlarının zaman zaman fakirlik ve toplumsal cinsiyet temelli baskılardan kaynaklanabildiği; bu kişilerin de istismara ve insan ticaretine karşı korunmasız kalabildiği gibi kesişmeler nedeniyle kavramları ayıran farkların her durumda net olmadığı da belirtilmektedir. ${ }^{36}$ Uluslararası İlişkiler ve Uluslararası Göç literatürüyle bağlantılı bir başka kavramsal tartışma ise bir sonraki bölümde ele alınacağ 1 gibi, insan ticareti, göçmen kaçakçılığ 1 ve düzensiz göç üzerinedir.

\footnotetext{
33 "UN Global Report on Trafficking in Persons 2016", s. 6.

${ }^{34}$ Agy, ss. 6-7.

${ }^{35}$ Konuya ilişkin kapsamlı analizler için bkz. Rochelle L. Dalla. Lynda M. Barker, John DeFrain, Cella Williamson, (ed.), Global Perspectives on Prostitution and Sex Trafficking, Lexington Books, Maryland, 2013; Mary Crawford, age.

${ }^{36}$ Mary Crawford, a.g.e., s.13.
}

\section{1}

Güvenlik Stratejileri

Cilt: 15

Sayı: 30 
Fulya MEMIşOĞLU

252

Güvenlik

Stratejileri

Cilt: 15

Say1: 30

\subsection{Kavramsal Tartışmalarda İnsan Ticareti, Göçmen Kaçakçılı̆̆ı ve Düzensiz Göç İlişkisi}

Düzensiz göç, bir ülkeye yasadışı yollardan giriş yapılması, bir ülkede yasadışı şekilde kalınması veya yasal yollarla girip yasal süre içerisinde çıkış yapılmaması durumlarını ifade etmek için kullanılmaktadır. ${ }^{37}$ Düzensiz göç dinamik yapısı nedeniyle ölçülebilirliği zor bir olgu olmakla birlikte, hem göçmenler açısından, hem de kaynak, transit ve hedef ülkeler açısından çeşitli zorluklar ve riskler barındırmaktadır. ${ }^{38}$ Dünyanın birçok bölgesinde göçmen kaçakçıları düzensiz göç sürecinin ayrılmaz bir parçası haline gelerek, devletlerin sınırlarını yönetme kabiliyetini azaltmakta, göçmenleri tehlikeli göç rotalarına yöneltmekte ve bu durumdan büyük kazançlar elde etmektedir. Bu bağlamda, göçmen kaçakçıllğı (migrant smuggling) da insan ticareti gibi küresel bir sorun olarak karşımıza çıkmaktadır. Bu iki kavram arasında benzerlikler ve bağlantılar olduğu gibi, öncelikle temel farklara kısaca değinmekte fayda görülmektedir. "BM Sınıraşan Örgütlü Suçlarla Mücadele Sözleşmesi” kapsamında insan ticaretini tanımlayan ek Protokolün yanı sıra, göçmen kaçakçıllı̆ııı tanımlayan ek "Kara, Deniz ve Hava Yoluyla Göçmen Kaçakçılığına Karşı Protokol" kabul edilmiştir. Protokolde göçmen kaçakçılığ "direkt veya dolaylı olarak mali veya herhangi bir maddi çıkar sağlama amacıyla bir kişinin daimi ikamet sahibi veya vatandaşı olmadiğı bir ülke içerisine yasadışı girişinin sağlanması" olarak tanımlanmaktadır. ${ }^{39}$

Göçmen kaçakçılığının temel unsurlarından biri, göçmenlerin kaçakçılar vasıtasıyla uluslararası bir sınırı yasadışı yollarla geçmesi ya da geçmeye teşebbüs etmesidir. İnsan ticareti ise uluslararası sınırlar arasında hareket gerektirmemektedir; bir ülkenin kendi sınırları

37 Göç İdaresi Genel Müdürlüğü Resmî İnternet Sayfas1, http://www.goc.gov.tr/ icerik6/genel-bilgi_409_422_423_icerik (Erişim Tarihi: 01.12.2018).

${ }^{38}$ Düzensiz göç üzerine kavramsal ve teorik tartışmalar için bkz. Anna Triandafyllidou, Irregular Migration in Europe: Myths and Realities, Taylor and Francis, London, 2010.

${ }^{39}$ Siniriaşan Örgütlü Suçlarla Mücadele Sözleşmesine ek Kara, Deniz ve Hava Yoluyla Göçmen Kaçakçılığına Karşı Protokol, Viyana, Birleşmiş Milletler, Aralık 2000. 
Uluslararası İlişkiler ve Uluslararası Göç Bağlamında İnsan Ticareti

içerisinde de bireylerin fiziksel ve/veya psikolojik olarak istismar edilmesi, kandırılması, baskı ve şiddete maruz kalarak sömürülmesi gerçekleşmektedir. ${ }^{40}$ Göçmen kaçakçılığında başlıca amaç, göçmenin çoğu zaman rızası ile sınırın yasadışı yollardan geçişini sağlamak iken, hedefe ulaşıldığında göçmen ve kaçakçı arasındaki ilişkinin son bulduğu öngörülmektedir. Buna karşıllk, insan ticaretini oluşturan durumlarda mağdur en başta eylemin gerçekleşmesi için rıza göstermiş olabilse de, insan tacirinin kullandığ 1 araçlar nedeniyle başta gösterilen rıza hukuki alanda anlamını yitirir ve kişinin istismarına sebep olan suç eylemi oluşturur (Bkz. Tablo 1).

Temelde ticari bir ilişki içeren göçmen kaçakçıllı̆̆ aynı zamanda devlet aleyhine ve kamu düzenine karşı işlenmiş bir suç olarak kabul edilmektedir. ${ }^{41}$ İnsan ticareti ise ağır insan hakları ihlalleri içeren bireye karşı işlenen bir suç olarak tanımlanmaktadır. ${ }^{42}$ İki kavram arasında hukuki farkl11ıklar üzerinden geliştirilen politikaların devletlerin ve devlet olmayan aktörlerin her iki mevzuyla daha etkin mücadele edebilmesini sağlayacağını savunan görüşler yaygındır. Ancak insan ticareti ve göçmen kaçakçılığı üzerine araştırma yapanların sıkça dile getirdiği önemli bir çekince, bu iki alan arasındaki sınırların realitede her zaman çok net olmadığı ve birçok örnekte kesiştiği yönündedir. ${ }^{43}$ Nitekim göçmen kaçakçılığında da göçmenler mağdur durumuna düşebilmekte, ya da göçmen kaçakçılığı esnasında veya sonrasında kişiler insan ticareti unsurları içeren bir durumla karşı karşıya

\footnotetext{
${ }^{40}$ John Salt, "Trafficking and Human Smuggling: A European Perspective", International Migration, 2000, Cilt 38, No 1, ss. 31- 56; Khalid Koser, "The smuggling of Refugees", David Kyle ve Rey Koslowski, (ed.), Global Human Smuggling: Comparative Perspectives, Johns Hopkins University Press, Baltimore, 2001, ss. 256-272.

${ }^{41}$ Brian Iselin ve Melanie Adams, Distinguishing between Human Trafficking and People Smuggling, Bangkok, Regional Centre for East Asia and the Pacific, UN Office on Drugs and Crime (UNODC), Vienna, 2003, s. 3.

${ }^{42}$ Tom Obokata, "Trafficking of Human Beings as a Crime Against Humanity: Some Implications for the International Legal System", The International and Comparative Law Quarterly, 2005, Cilt 54, Say1 2, ss. 445-457.

${ }^{43}$ Andrea Di Nicola, a.g.e., s. 65.
} 
Güvenlik

Stratejileri

Cilt: 15

Sayı: 30

kalabilmektedir. ${ }^{44}$ Tablo 2'de görüldüğü üzere, hukuki statüye dayanan kavramsal ayrıştırmalarla belirlenen farklı göçmen kategorileri göçmenlere yönelik istismarın ve karşılaştıkları mağduriyetlerin zaman zaman göz ardı edilmesine yol açabilmektedir. ${ }^{45}$

Tablo 2: Kavramlar Arasında Farklar ve Kesișmeler.

\begin{tabular}{|c|c|c|c|c|c|}
\hline & $\begin{array}{c}\text { Göç } \\
\text { sürecine } \\
\text { üçüncü } \\
\text { bir kişinin } \\
\text { dâhil } \\
\text { olması }\end{array}$ & $\begin{array}{c}\text { Kişinin } \\
\text { ülkeler } \\
\text { arası } \\
\text { göç } \\
\text { etmesi }\end{array}$ & $\begin{array}{c}\text { Kişinin } \\
\text { hukuki } \\
\text { koruma } \\
\text { altında } \\
\text { olmaması }\end{array}$ & $\begin{array}{c}\text { Kişiye } \\
\text { yönelik } \\
\text { istismar }\end{array}$ & $\begin{array}{c}\text { Kişinin } \\
\text { göç etmesinin } \\
\text { zorunlu } \\
\text { bir nedenden } \\
\text { dolayı } \\
\text { gerçekleşmesi }\end{array}$ \\
\hline Göçmen & Mümkün & Mümkün & Mümkün & Mümkün & Mümkün \\
\hline Mülteci & Mümkün & Evet & Mümkün & Mümkün & Evet \\
\hline $\begin{array}{c}\text { Göçmen } \\
\text { kaçakçılığına } \\
\text { maruz kalmış kişi }\end{array}$ & Evet & Evet & Evet & Mümkün & Mümkün \\
\hline $\begin{array}{c}\text { Insan ticaretine } \\
\text { maruz kalmış kişi }\end{array}$ & Evet & Mümkün & Mümkün & Evet & Mümkün \\
\hline $\begin{array}{c}\text { Belgesiz/düzensiz } \\
\text { göçmen }\end{array}$ & Mümkün & Mümkün & Evet & Mümkün & Mümkün \\
\hline
\end{tabular}

Kaynak: Başta UNODC raporları olmak üzere, yazar tarafından farklı kaynaklardan yararlanarak düzenlenmiştir.

Devletlerin düzensiz göçle mücadele kapsamında uyguladıkları sınırlayıcı iltica ve göç politikaları birçok kişiyi göçmen kaçakçıları ya da insan tacirlerine mecbur bırakmaktadır. ${ }^{46}$ 1990'ların başlarından

${ }^{44}$ Bu tür kesişmeleri ampirik araştırma sonuçlarına dayanarak anlatan kapsamlı bir çalışma için bkz. "Smuggling and Trafficking: Rights and Intersections", Global Alliance Against Traffic in Women (GAATW) Working Paper Series, 2011, https://ec.europa.eu/antitrafficking/sites/antitrafficking/files/smuggling_and_trafficking._rights_and_intersections_1 .pdf (Erişim Tarihi: 01.12.2018).

${ }^{45}$ Sarah Pierce, "The Vital Difference Between Human Trafficking and Migrant Smuggling", 12 Kasim 2014, https://www.opendemocracy.net/beyondslavery/sarah-pierce/vital-differen ce-between-human-trafficking-and-migrant-smuggling (Erişim Tarihi: 01.12.2018).

${ }^{46}$ Maggy Lee, "Introduction: Understanding Human Trafficking", Maggy Lee, (ed.), 
Uluslararası İlişkiler ve Uluslararası Göç Bağlamında İnsan Ticareti

itibaren artan düzensiz göç hareketlerini kontrol etmek amacıyla, hedef konumundaki devletlerin göç ve iltica politikalarını güvenlik eksenli geliştirmesi ve sınır güvenliği alanında önlemlerin arttırılması, göçmen ve sı̆̆ınmacıların uluslararası sınırları geçebilmek için kaçakçılara bağımlılığını arttırmıştır. Nitekim 2015'te AB'ye düzensiz göç rotalarıyla ulaşan bir milyondan fazla göçmenin \%90'dan fazlasının yolculukları esnasında göçmen kaçakçılarından yardım aldığı saptanmıştır. $^{47}$ Düzenli ve güvenli göç kanallarının sınırlı olması, uluslararası koruma sisteminin yetersizlikleri nedeniyle sığınmacıların da düzensiz göç yollarına sıklıkla mecbur kalması, göçmen kaçakçılığ ve insan ticareti şebekelerinin bu kişilerin hassasiyetlerini istismar etmesi gibi birçok sorunu da beraberinde getirmektedir. $\mathrm{Bu}$ tür hassasiyetler, mülteciler ve yerinden edilmiş grupları -bu gruplar içerisinde de özellikle yetim ve refakatsiz çocukları- suç örgütleri tarafindan insan ticaretinin yeni hedef kitleleri konumuna getirebilmektedir. $^{48}$ 2010-2016 y1lları arasında özellikle refakatsiz göçmen ve mülteci çocuk sayısının 80 ülkede beş kat artarak 300.000’e ulaşmış olması, bu kırılgan grubun insan ticareti ve çeşitli istismar türlerine karşı korunmasız olduğuna dikkat çekmektedir. ${ }^{49}$ Göçmenlerin, kaçakçılar ve sınır yetkilileri tarafindan maruz kaldıkları şiddet eylemleri karşılaştıkları risklerin sadece küçük bir kısmıdır. ${ }^{50}$ Uluslararası Göç Örgütü (IOM) Kayıp Göçmenler Projesi kapsamında, 2000'li yılların başından itibaren 46.000'den fazla göçmenin riskli düzensiz göç rotaları neticesinde hayatını kaybettiği, 2016 ve 2017'de ise yıllık ölüm rakamlarının 1000'e ulaştığ 1 belirtilmektedir. ${ }^{51}$

a.g.e., s. 21.

47 "Migrant smuggling in the EU”, EUROPOL, 2016, s.2, https://www.europol.europa.eu/ publications-documents/migrant-smuggling-in-eu (Erişim Tarihi: 01.12.2018).

${ }^{48}$ UNICEF, "Harrowing Journeys: Children and youth on the move across the Mediterranean Sea, at risk of trafficking and exploitation", 2017, https://www.unicef.org/publications/ index_100621.html (Erişim Tarihi: 01.12.2018).

${ }^{49} \mathrm{UNICEF}$, a.g.y., ss. 6-8.

${ }^{50}$ David Kyle ve Rey Koslowski, (ed.), a.g.e., s. 3.

51 IOM, "Missing Migrants Project", 2018, https://missingmigrants.iom.int (Erişim 
Kavramsal tartışmalara yön veren temel bir husus ise, göçmen

Güvenlik Stratejileri

Cilt: 15

Sayı: 30 kaçakçılığına ilişkin rıza kavramıdır. Yukarıda bahsedildiği üzere, göçmen kaçakçılığında başlıca amaç, göçmenin çoğu zaman rızası ile sınırın yasadışı yollardan geçişini sağlamak iken, hedefe ulaşıldığında göçmen ve kaçakçı arasındaki ilişkinin bittiği yönündendir. $\mathrm{Bu}$ nedenle, insan ticareti ve göçmen kaçakçılığına ilişkin protokoller arasındaki temel farklardan biri, bu iki duruma maruz kalan kişilere sağlanan koruma çerçevesidir. İnsan ticareti mağdurları açısından kapsamlı bir koruma çerçevesi oluşturulmuşken, göçmen kaçakçıllı̆̆ından etkilenen göçmenlere karşı sunulan koruma çerçevesi minimal düzeydedir. $\mathrm{Bu}$ konuyu küresel göç yönetişimi çerçevesinde daha kapsamlı bir açıdan değerlendiren Betts, mülteci rejimi dışında kalan ancak hassas durumda olan göçmenlerin haklara erişiminin kısıtlı olduğundan; hassas göçmen gruplara yönelik uluslararası insan hakları mekanizmalarının yetersizliğinden ve bu gibi mekanizmaların güçlendirilmesinde karşılaşılan zorluklardan bahseder. ${ }^{52}$ Bu husus BM Küresel Göç Mutabakatı üzerine yapılan tartışmalar ve müzakerelerde de önemli bir başl1k oluşturmuş; üye devletler tarafindan kabul edilen nihai belgede statüye bakılmaksızın göçün her aşamasında göçmenlerin insan haklarına saygı gösterilmesi gerekliliği vurgulanmıştır. ${ }^{53}$ Göçmenlere yönelik koruma çerçevesinin güçlendirilmesi amacıyla mutabık kalınan hedefler arasında düzenli göç yollarına erişimin arttırılması ve esnek hale getirilmesi (Hedef 5); göçmenlerin yolculukları boyunca karşılaştıkları -özellikle toplumsal cinsiyet, yaş ve engellilik temelli- hassasiyetlerin göz önünde bulundurularak insan haklarının korunması, desteklenmesi ve karşılaştıkları ayrımcılıkla mücadele edilmesi (Hedef 7) sayllabilir. ${ }^{54}$

Tarihi: 01.12.2018).

${ }^{52}$ Alexander Betts (ed.), Global Migration Governance, Oxford University Press, New York, 2011, s. 39.

53 "Global Compact for Safe, Orderly and Regular Migration, Intergovernmentally Negotiated and Agreed Outcome", a.g.y., s. 3.

${ }^{54}$ A.g.y., s. 5. 


\section{2. İnsan Ticareti üzerine Teorik Tartışmalar}

İnsan ticaretinin göç, güvenlik, insan hakları, toplumsal cinsiyet, kriminolojik, ekonomi politik gibi çeşitli boyutlarını analiz eden çalışmalar 2000'lerin başından itibaren çoğalmaktadır. IOM tarafından 2005 yılında hazırlanan küresel insan ticareti kaynakça taramasında belirtildiği üzere, yapılan çalışmaların yaklaşık \%80'ini Avrupa ve Asya bölgeleri üzerinde yoğunlaşmıştır. ${ }^{55}$ Buna karşılık, Orta Doğu, Amerika ve Afrika üzerine bölgesel çalışmaların az sayıda olduğu dikkat çekmektedir. ${ }^{56}$ Ayrıca mevcut çalışmaların büyük bir kısmı kadınların ve çocukların cinsel sömürü amaçlı istismarına odaklanmış olup, insan ticaretinin diğer biçimleri üzerine araştırmaların daha sınırlı sayıda olduğu görülmektedir. Bir önceki bölümde ele alınan kavramsal tartışmalara benzer olarak, teorik tartışmalarda da dikkat çeken başlıca mevzu, insan ticareti olgusunun tam olarak kuramlaştırılmamış ve parçalanmış olmasıdır. ${ }^{57}$

Öncelikle, insan ticaretini uluslararası göç kuramları bağlamında inceleyen çalışmalar çoğunluktadır. Bu çalışmaların önemli bir kısmı, insan ticareti ve kadınların mağduriyeti arasındaki bağlantıya odaklanarak, işgücü sömürüsünde kadınların konumu, fakirliğin feminizasyonu, kadınların hem çekirdek aile, hem toplum içerisindeki ikincil konumlarına neden olan yapısal durumları incelemektedir. ${ }^{58}$ Neticede uluslararası ölçekte kadın göçünün artmasıyla birlikte, göçün istismar ve yasadış1 öğeler içeren türlerinin de arttığına dikkat çekilmektedir. Sıkça analiz edilen bir başka boyut ise, göç politikaları kapsamında özellikle hedef ülke konumundaki ülkelerin insan ticaretine nasıl yaklaştığı üzerinedir.

\footnotetext{
${ }^{55}$ Frank Laczko, a.g.m., s.8.

${ }^{56}$ A.g.m., s.8.

${ }^{57}$ Ann Jonsson, "Introduction: Human Trafficking and Human Security in the Baltic Sea Region", Ann Johnsson, (ed.), Human Trafficking and Human Security, Routledge, New York, 2009, s.15; Cornelius Friesendorf, "Pathologies of Security Governance: Efforts Against Human Trafficking in Europe", Security Dialogue, 2007, Cilt 38, No 3, s. 382.

${ }^{58}$ Bkz. Maggy Lee, age, 2007; Mary Crawford, age 2010; Louise Shelley, age, 2010; Shiro Okubo ve Louise Shelley, a.g.e., 2011.
}

\section{7}

Güvenlik Stratejileri

Cilt: 15

Say1: 30 

İnsan ticaretinin çoğu hedef ülke tarafından düzensiz/yasadışı göçle eş değer görüldüğ̈ ve bu nedenle ulusal güvenliğe yönelik bir tehdit olarak algılandığı savunulmaktadır. ${ }^{59} \mathrm{Bu}$ durum insan ticareti mağdurlarının suçlu olarak algılanmasına ve düzensiz göçmenlere uygulanan sınırdışı etme politikalarına insan ticareti mağdurlarının da maruz kalmasına neden olmaktadır. ${ }^{60}$ Göçmenler açısından ise, düzensiz yollarla göç etmek hedef ülkelerin giderek kısıtlayıcı hale gelen göç ve iltica politikalarından dolayı tek çıkar yol haline gelebilmektedir. Diğer taraftan insan ticaretinin sadece düzensiz göç sonucunda gerçekleşmediği, düzenli göçün de insan ticaretine yol açabileceği göz önünde bulundurulmalıdır. ${ }^{61}$ Örneğin insan tacirleri belirli bir ülkeye giriş yapmak için yasal göç yollarının kullanımını kaynak ve transit ülkelerde oluşan destek piyasaları aracılığıyla manipüle edebilmektedir. Seyahat, iş bulma, evlilik işletmeleri gibi kuruluşlardan oluşan bu tür destek piyasalarını Kazakistan, Tacikistan, Türkmenistan, Kırgızistan ve Özbekistan gibi Orta Asya ülkeleri üzerinden incelediği çalışmasında, Shelley, bu kuruluşların göçün gerçekleşmesinde kolaylaştırıcı rol oynadığını, ancak çoğu zaman gayriresmî olarak faaliyet gösterdiğini ve denetlenmediğini, insan tacirleri tarafından da kullanılabildiğini vurgulamaktadır. $^{62} \mathrm{Bu}$ gibi durumlar karşısında insan ticareti ve düzenli/düzensiz nüfus hareketleri arasındaki keskin ayrımlar bulanıklaşmaktadır. Salt ise insan ticareti ve göçle ilintili teorik tartışmaları farklı bir açıdan ele almakta ve bunların temel olarak birbirini tamamlayan iki yaklaşım olduğunu ileri sürmektedir. ${ }^{63}$ Bunlardan birincisi, insan ticaretini ekonomik bir bakış açısıyla ele alan ve bir iş olarak gören yaklaşım; ikincisi ise, insan ticaretini bir suç aktivitesi

${ }^{59}$ Maggy Lee, a.g.e., 2007, s. 20.

${ }^{60}$ Margaret E. Beare, "Illegal Migration: Personal Tragedies, Social Problems, or National Security Threats?", P. Williams der., Illegal Immigration and Commercial Sex: The New Slave Trade, Frank Cass, London, 1999, ss. 11-41.

${ }^{61}$ Ronald Skeldon, "Trafficking: A Perspective from Asia", International Migration, 2000, Cilt 38, No 3, s. 7.

${ }^{62}$ Louise Shelley, a.g.e., 2010.

${ }^{63}$ John Salt, a.g.m., s. 35. 
olarak ele alan ve yasal düzenlemeleri birincil plana koyan yaklaşımdır. $\mathrm{Bu}$ bağlamda insan ticaretinin ve göçmen kaçakçılığının özünde ekonomik birer aktivite olduğunu ve göçün daha geniş bir teorik çerçevede resmî ve gayriresmî kurumların kâr elde etmeye çalıştı̆ğ bir sektör olarak kuramlaştırılması gerektiğini ileri sürer.

Uluslararası ilişkiler disiplininde ise insan ticareti üzerine teorik tartışmalara yön veren başlıca kavramlardan biri güvenliktir. Bu tartışmalar genel hatlarıyla insan ticaretini devletlerin güvenliğine yönelik bir tehdit olarak ele alan geleneksel güvenlik yaklaşımı ve insan ticaretini bir insan güvenliği meselesi olarak irdeleyen genişletilmiş güvenlik yaklaşımı çerçevesinde şekillenmiştir. ${ }^{64}$ Bir önceki bölümde aktarıldığı üzere, insan ticaretinin uluslararası politika alanında artan önemi de Soğuk Savaş sonrası değişen şartlara göre güvenlik kavramının dönüşüme uğramış olmasıyla yakından ilintilidir. Öncelikle 1950'li y1llardan itibaren realizmle özdeşleştirilen geleneksel güvenlik yaklaşımı insan ticaretini devletlerin egemenliğine bir tehdit olarak değerlendirmektedir. $\mathrm{Bu}$ bağlamda, insan ticaretiyle mücadelede vurgulanan başlica hususlar uluslararası göçün kontrolü, sınır güvenliğinin arttırılmas1 ve düzensiz göçmen olarak görülen insan ticareti mağdurlarının ivedilikle sınır dışı edilmesidir. ${ }^{65}$ Ancak insan ticaretinin devlete yönelik bir tehdit olarak kuramlaştırılması iki temel sorunu da beraberinde getirmektedir. Birincisi, bu yaklaşımın insan ticareti mağdurlarının devletlerin korumakla yükümlü olduğu bireysel hak ve özgürlüklerini göz ardı etmesidir. ${ }^{66}$ İkinci sorun ise, realizm ve liberalizm gibi ana akım uluslararası ilişkiler teorilerinin uluslararası sistemin yeniden yapılandırılmasını mümkün kılan hak temelli normlar ve fikirlere yeterince vurgu yapmamasıdır. ${ }^{67} \mathrm{Bu}$ durumdan kaynaklı

\footnotetext{
${ }^{64}$ Ann Jonsson, a.g.e., ss. 15-17.

65 Jennifer K. Lobasz, "Beyond Border Security: Feminist Approaches to Human Trafficking", Security Studies, 2013, Cilt 18, Say1 2, s. 322.

${ }^{66}$ A.g.m., s. 323.

${ }^{67}$ Marta Iniguez de Heredia, "People Trafficking: Conceptual issues with the United Nations Trafficking Protocol 2000", Human Rights Review, 2008, Cilt 9, No 3, ss. 299
}

Cilt: 15

Sayı: 30 
olarak, devlet-odaklı güvenlik yaklaşımı insan ticareti gibi özünde insan güvenliğini tehdit eden ve uluslararası düzeyde iş birliği gerektiren konuları küresel politika gündemine taşımakta yetersiz kalmıştr. ${ }^{68}$

Cilt: 15

Soğuk Savaş'ın bitmesiyle birlikte, güvenlik kavramının

Sayı: 30 küreselleşmenin çok yönlü etkilerinin göz önünde bulundurulduğu bir biçimde derinleştirilmesi ve genişletilmesi gerektiği Uluslararası İlişkiler disiplininde yeni bir tartışma başlatmıştır. ${ }^{69} \mathrm{Bu}$ tartışmaların temelinde 1990'ların ortasından itibaren küreselleşmenin yoğunlaşmasına neden olan ekonomik ve siyasi liberalleşme süreçleri, yeni bilgi ve iletişim teknolojilerinin gelişmesi ve bu üç etmenin birbirini güçlendirmesinin, toplumsal ve bireysel hayatın birçok alanında hızlı değişimlere yol açması yatmaktadır. ${ }^{70}$ Genişletilmiş güvenlik yaklaşımına göre bu tür değişimler aynı zamanda toplumlar açısından yeni güvensizlik alanları yaratarak, devlet-odaklı güvenlik konularının yanı sıra, insan ticareti gibi belli bir coğrafyaya sınırlı kalmayıp tüm toplumları tehdit eden yeni sorunların, toplumsal cinsiyet gibi unsurlar göz önünde bulundurularak uluslararası gündeme taşınmasını gerektirmektedir. ${ }^{71}$ İnsan ticaretini bu çerçevede kuramlaştıran çalışmalar, dikkati insan güvenliğine çekerek hem toplumlar, hem mağdurlar açısından daha kapsamlı analizler sunmaktadır. ${ }^{72}$

-316; Jacqui True, "Feminism", Scott Burchill, (ed.), Theories of International Relations, Palgrave MacMillan, New York, ss. 231-76.

${ }^{68}$ Aninia Nadig, "Human Smuggling, National Security, and Refugee Protection", Journal of Refugee Studies, 2002, Cilt 15, No 1, s.2; Marta Iniguez de Heredia, a.g.m., s. 312.

69 Mariam Georgis and Nicole V.T. Lugosi, "(Re)inserting race and indigeneity in international relations theory: a post-colonial approach", Global Change, Peace \& Security, 2013, Cilt 26, No 1, s.73; Ralf Emmers, "Globalization and Non- Traditional Security Issues: A Study of Human and Drug Trafficking in East Asia”, RSIS Working Paper, 2004, No. 62, s. 1.

${ }^{70}$ Ralf Emmers, a.g.m., s. 1.

${ }^{71}$ Konuyla ilgili kapsamlı analizler için bkz. Barry Buzan, Ole Wæver and Jaap de Wilde, Security: A New Framework for Analysis, Lynne Rienner Publishers, Boulder, 1998; Matt McDonald, "Human Security and the Construction of Security", Global Society, 2002, Cilt 16, No 3, ss. 277-295; Stephen M. Walt, "The Renaissance of Security Studies", International Studies Quarterly, 1991, Cilt 35, No 2, ss. 211-239.

${ }^{72}$ Ann Jonsson, a.g.e., 2009; Shiro Okubo ve Louise Shelley, Human Security, 
$\mathrm{Bu}$ bağlamda konuyu feminist yaklaşımdan ele alan çalışmalar analitik odağ 1 devletler yerine bireylere kaydırarak, insan ticareti mağdurlarının güvenliğine yönelik tacirler, kolluk kuvvetleri ve işverenlerin neden olduğu çeşitli tehditlere dikkat çekmektedir. Lobasz'ın ifade ettiği üzere, güvenlik tehdidi anlayışının insan-odaklı biçimde genişletilmesi insan ticaretiyle mücadeleye yönelik politikaların da suçun önlenmesi ve mağdurların etkin bir biçimde korunmasını sağlayacak yönde geliştirilmesine firsat sunmaktadır. ${ }^{73}$ Benzer biçimde insan ticaretini eleştirel teori çerçevesinde irdeleyen çalışmalar konuyu bir insan güvenliği sorunu olarak değerlendirmekte ve mücadelede uluslararası iş birliğinin önemini vurgulamaktadır. Temelinde insanların özgürleştirilmesini savunan eleştirel teori açısından, insan ticaretinin Uluslararası İlişkiler disiplini kapsamında bir insan güvenliği sorunu olarak kuramlaştırılmasının zulüm, baskı ve tehdidin neden olduğu küresel adaletsizliklerin de düzeltilmesine katkıda bulunacağı ifade edilmektedir. ${ }^{74}$ Emmers'a göre küreselleşen dünyada bir kâr güdüsü olduğu sürece, insanlar ucuz işgücü ve cinsel sömürüsünden kâr elde edilen ve bu yönde ticareti yapılan birer meta haline dönüşmeye devam edecektir. ${ }^{75} \mathrm{Bu}$ gibi sınıraşan bir suçla mücadelenin yolu ise hükümetlerin bireysel çabalarıyla değil, ancak bilgi paylaşımı, iade hukuku, yolsuzlukla ortak mücadele gibi farklı boyutlar içeren kapsamlı bir uluslararası iş birliği çerçevesinde gerçekleşebilir. ${ }^{76}$

$\mathrm{Bu}$ yaklaşımla bağlantılı olarak, Friesendorf, insan ticaretiyle mücadelenin ne tür bir uluslararası iş birliği çerçevesinde geliştirilmesi gerektiğini güvenlik yönetişimi (security governance) kavramıla açıklar. ${ }^{77}$ Bu kavramın temelinde yatan temel varsayım insan ticareti

Transnational Crime and Human Trafficking: Asian and Western Perspectives, Routledge, New York, 2011.

${ }^{73}$ Jennifer K. Lobasz, a.g.m., s. 319.

${ }_{75}^{74}$ Mariam Georgis and Nicole V.T. Lugosi, a.g.m., s.73.

${ }^{75}$ Ralf Emmers, a.g.m., s. 5.

${ }^{76}$ Agm, s.5; Marta Iniguez de Heredia, a.g.m., s. 303.

${ }^{77}$ Cornelius Friesendorf, a.g.m., ss. 379-402. 
262

Güvenlik Stratejileri

Cilt: 15

Sayı: 30

gibi devlet olmayan aktörlerin neden olduğu yasadışı suç faaliyetlerinin engellenmesinde geleneksel ve hiyerarşik karakterdeki ulusal karar alma ve uygulama yapılarının yetersiz kalmasıdır. Devletlerin bu tür suçlarla ancak uluslararası iş birlikleri oluşturarak mücadele edebileceği, fakat iş birliği mekanizmalarının da devletlerle sınırlı kalmayıp uluslararası kuruluşların, sivil toplum örgütlerinin ve özel sektör aktörlerinin dâhil edildiği kapsayıcı bir yapıda gelişmesi gerekmektedir. Başka bir deyişle, insan ticaretiyle mücadele alanı hiyerarşik yönetim anlayışından çoklu aktör arasında birlikte iş yapma vurgusunun ön plana çıktığ 1 yönetişim anlayışına doğru bir paradigma kaymasını gerektirmektedir. ${ }^{78}$ Bir sonraki bölümde insan ticaretiyle mücadele alanının insan güvenliğini ön plana çıkaran bir yaklaşımla göç politikaları kapsamında nasıl geliştiği Türkiye örneği üzerinden değerlendirilecektir.

\section{Türkiye'de İnsan Ticaretiyle Mücadele Alanında Güncel Gelişmeler}

İnsan ticaretine karş1 mücadele; devletlerin, uluslararas1 kuruluşların, sivil toplum örgütlerinin ve araştırmacıların bu alandaki bütün faaliyetlerini kapsamaktadır. Konuyla mücadeleye yönelik kuramsal çalışmalar literatürde politika analizi, norm geliştirme ve uygulama ve en iyi uygulama çalışmaları olmak üzere üç başlık altında toplanmaktadır. ${ }^{79}$ Bu yaklaşımların ortak vurguladığı husus, diplomasi dünyasının rasyonel hareket eden ve kendi çıkarlarına göre seçimler yapan devletlerden oluştuğu yönündedir. Politika analizi yaklaşımı yaş, cinsiyet, etnik köken gibi politika parametrelerine farklı parametrelerin de dâhil olmasını inceler ve bu ölçütlerin genel bir değerlendirmesini sunar. ${ }^{80}$ Insan ticaretiyle mücadeleyi bir norm olarak görenler ise, insan ticaretinin nasıl geliştiğini göstermeye çalışır. Locher'e göre, insan ticareti ile mücadele çok çabuk kabul görmüştür, çünkü insan hakları,

\footnotetext{
${ }_{78}^{78}$ A.g.m, ss. 383-4.

${ }^{79}$ Reyhan Atasü-Topçuoğlu, Ideology and the Fight Against Human Trafficking, Routledge, New York, 2014, s. 20.

${ }^{80}$ A.g.e., s. 20.
} 
kadın hakları, şiddet karşıtlığı, cinsiyet eşitliği ve kölelik karşıtlığı gibi kökleri sağlam olan diğer normlara dayanmaktadır. ${ }^{81} \mathrm{Hem}$ politika analizi, hem de norm geliştirme yaklaşımları, rasyonel seçim teorisine dayanmaktadır ve zaman içerisinde gelişen standartlara odaklanmaktadır. Standartların uluslararası düzeyde yaratıldığ 1 ve daha sonra ulusal düzeye yayıldığı ifade edilmektedir. ${ }^{82} \mathrm{Bu}$ bölümde ele alınacağı üzere, Türkiye'de insan ticaretiyle mücadele ulusal çerçevesi, bu alanda uluslararası standartların oluşumunu takiben 2000'li yılların başından itibaren hızla gelişmeye devam etmektedir. ${ }^{83}$

Türkiye, uluslararası göç sistemi içerisinde yakın döneme kadar göç veren ve transit özellikleri ile ön plana çıkan bir ülke konumundan, sosyo-ekonomik kalkınmaya yönelik yaşanan olumlu gelişmelerin de etkisiyle birlikte, hedef göç ülkesi konumu da giderek güçlenen bir doğrultuda ilerlemektedir. ${ }^{84}$ Bu durum, Türkiye'yi aynı zamanda insan ticareti için de bir hedef ülkesi haline getirmiştir. ${ }^{85} \mathrm{BM}$ Sınıraşan Örgütlü Suçlarla Mücadele Sözleşmesi'nin 2000 yılında imzalanması ve ilgili protokollerin 2003 yılında iç hukuka dâhil edilmesiyle birlikte, sözleşmenin yükümlülüklerini yerine getirmek amaciyla insan ticareti alanında çeşitli yasal ve idari düzenlemeler yapılmıştır. Öncelikle suçun kovuşturulması ve soruşturulması kapsamında 2005 yılında yürürlüğe

\footnotetext{
${ }^{81}$ Birgit Locher, Trafficking in Women in the European Union, Springer Publications, Wiesbaden, 2007.

${ }^{82}$ Reyhan Atasü-Topçuoğlu, a.g.e, s. 22.

83 "Sinırıaşan Örgütlü Suçlara Karşı BM Sözleşmesi” ve Sözleşemeye Ek “İnsan Ticaretinin, Özellikle Kadın ve Çocuk Ticaretinin Önlenmesine, Durdurulmasına ve Cezalandırılmasına İlişkin Protokolü” Türkiye tarafindan Aralık 2000 tarihinde imzalanmış, 04 Şubat 2003 tarihli Resmî Gazeteyle de iç hukuka dâhil edilmiştir.

${ }^{84}$ Fulya Memişoğlu, "Between the Legacy of Nation-State and Forces of Globalisation: Turkey's Management of Mixed Migration Flows", EUI RSCAS Working Paper Series, 2014, No. 122, s.3, http://cadmus.eui.eu/bitstream/handle/1814/33862/RSCAS_2014_ 122.pdf?sequence=1 (Erişim Tarihi: 12.03.2019).

${ }^{85}$ Türkiye'de mevcut durumun kapsamlı analizi için bkz. "2017 Türkiye İnsan Ticaretiyle Mücadele Yıllık Raporu”, Göç İdaresi Genel Müdürlüğü, Yayın No 48, Ankara, 2018, http://www.goc.gov.tr/files/files/INSAN-TICARETI-MAGDURLARI-RAPORU-2017mini.pdf (Erişim Tarihi: 01.12.2018).
}

\section{3}

Güvenlik Stratejileri

Cilt: 15

Sayı: 30 
264

Güvenlik Stratejileri

Cilt: 15

Sayı: 30

giren 5237 sayılı Türk Ceza Kanunu'nda (TCK) İnsan Ticareti Özel Hükümler kısmında "Uluslararası Suçlar" başlığı altında 80. Madde'de yaptırıma bağlanmıştır. İnsan ticaretine yönelik Ek Protokole uygun olarak TCK'da insan ticareti suçu şu şekilde düzenlemiştir:

"Zorla çalıştırmak, hizmet ettirmek, fuhuş yaptırmak veya esarete tâbi klmak ya da vücut organlarının verilmesini sağlamak maksadiyla tehdit, baskl, cebir veya şiddet uygulamak, nüfuzu kötüye kullanmak, kandırmak veya kişiler üzerindeki denetim olanaklarından veya çaresizliklerinden yararlanarak rızalarını elde etmek suretiyle kişileri ülkeye sokan, ülke dışına çıkaran, tedarik eden, kaçıran, bir yerden başka bir yere götüren veya sevk eden ya da barındıran kimseye sekiz yıldan on iki yıla kadar hapis ve on bin güne kadar adlî para cezast verilir."

Türkiye'de henüz insan ticareti ile mücadeleye özel bir kanun bulunmamaktadır. Ancak son yıllarda göç politikalarının yeniden yapılandırılması kapsamında insan ticaretiyle mücadele alanı da uluslararası standartlara uygun ve kapsayıcı şekilde revize edilmektedir. $\mathrm{Bu}$ alanda Türkiye'yle yakın iş birliği geliştirmiş bir uluslararası kuruluş yetkilisinin ifade ettiği üzere, özellikle 2010 sonrası dönemde insan ticareti göç yönetimi çerçevesinin ayrılmaz bir parçası haline gelmiş ve konunun politika alanında önemi artmıştır. ${ }^{87}$ Göç alanında başka bir uzman ise, insan ticaretiyle ulusal mücadele sürecini etkileyen faktörleri dışsal ve içsel olmak üzere ikiye ayırıp, konuyu daha analitik bir yaklaşımla açıklamıştır. ${ }^{88}$ Görüşmeciye göre, insan ticaretiyle mücadele alanında uluslararası normların oluşması Türkiye' de de ilgili aktörlerin konuya yönelik farkındalık duymasını sağlamıştır. Farkındalığın ortaya çıkmasında da özellikle ABD'nin Türkiye de dâhil olmak üzere

86 Türk Ceza Kanunu tam metin için bkz. Resmî Gazete No 25611, 2004, http://www.mevzuat.gov.tr/Metin1.Aspx?MevzuatKod=1.5.5237\&Mevzuatlliski=0\&sourc eXmlSearch $=\&$ Tur=1\&Tertip=5\&No=5237 (Erişim Tarihi: 12.03 .2019$)$.

${ }^{87}$ Mülakat 1, Aralık 2017, Ankara.

${ }^{88}$ Mülakat 2, Aralık 2017, Ankara. Paragrafin geri kalan kısmı Mülakat 2 bulgularından özetlenmiştir. 
diğer ülkeler hakkında yayınladığı yıllık insan ticareti raporları, Türkiye'nin $\mathrm{AB}$ müktesebatına uyum süreci, uluslararası kuruluşların düzenlediği eğitim faaliyetleri gibi dışsal faktörlerin etkili olduğu belirtilmiştir. 2000-2010 yılları arasında insan ticaretiyle mücadeleye yönelik ulusal düzenlemeler yapılmasını da bu tür dışsal faktörler tetiklemişken, 2010 sonrası döneme daha çok içsel faktörler yön vermeye başlamıştır. İnsan ticaretiyle mücadeleye yönelik farkındalığın olgunlaşması ve yayılmasının da etkisiyle, bu alanda atılması gereken adımlar göç yönetiminin insan hakları temelli bir yaklaşımla reform edildiği sürecin bir parçası olarak kabul görmüştür.

$\mathrm{Bu}$ bağlamda 2013 yılında yürürlüğe giren Yabancilar ve Uluslararası Koruma Kanunu'nun (YUKK) insan ticaretiyle mücadelede insan güvenliği ve mağdur odaklı bir politika benimsenmesinde dönüm noktası olduğu söylenebilir. ${ }^{89}$ Öncelikle insan ticareti mağdurlarının sınır dış1 edilemeyeceği ilkesi uluslararası standartlara uygun olarak kanunda güvence altına alınmıştır. ${ }^{90}$ Göç uzmanı bir yetkili, kanun tasarısı hazırlama sürecinde insan ticaretiyle mücadele alanının da gözden geçirildiğini, zayıf yönler belirlenerek bu doğrultuda özellikle mağdurların korunması, mağdurlara ikamet izni verilmesi, ulusal yönlendirme/koordinasyon mekanizmasının güçlendirilmesi gibi düzenlemelerin de Kanun metnine eklendiğini belirtmiştir. ${ }^{91}$ Nitekim YUKK insan ticareti mağdurlarına tedavi, bakım ve düşünme süresi ve sonrasinda Türkiye'de belirli bir süre ikamet edebilme olanağ1 tanımıştır. ${ }^{92} 2016$ 'da yürürlüğe giren Uluslararası İşgücü Kanunu'nda ise, YUKK uyarınca, mağdur destek sürecinden yararlanan insan ticareti mağdurları çalışma izninin istisnai olarak verilebileceği yabancılar

\footnotetext{
${ }^{89}$ Yabancılar ve Uluslararası Koruma Kanunu (YUKK) tam metin için bkz. Resmî Gazete No 28615, 2013, http://www.resmigazete.gov.tr/eskiler/2013/04/20130411-2.htm (Erişim Tarihi: 01.12.2018).

${ }^{90}$ Bkz. YUKK Madde 55.

${ }^{91}$ Mülakat 3, Aralık 2017, Ankara.

${ }^{92}$ Bkz. YUKK Madde 48-49.
}

\section{5}

Güvenlik Stratejileri

Cilt: 15

Sayı: 30 


\section{6}

Güvenlik Stratejileri

Cilt: 15

Sayı: 30

arasında tanımlanmıştır. ${ }^{93}$

YUKK'un yürürlüğe girmesiyle birlikte, göç yönetimi ve uluslararası korumadan sorumlu hale gelen Göç İdaresi Genel Müdürlüğü (GIGM), aynı zamanda insan ticareti alanında ulusal koordinatör rolünü Dışişleri Bakanlığı'ndan devralmıştır. ${ }^{94}$ GÍGM bünyesinde kurulan İnsan Ticareti Mağdurlarını Koruma Dairesi Başkanlığı, insan ticareti alanında veri toplama ve araştırma, mücadelede temel boşlukların tespiti, hizmetlerin iyileştirilmesi, ulusal koordinasyonun güçlendirilmesi, sivil toplum kuruluşları ve uluslararası kuruluşlarla iş birliği, ortak projeler yürütülmesi gibi görevleri yerine getirmektedir. ${ }^{95}$ Mağdurlara erişimde temel bir araç olarak hizmet veren "İnsan Ticareti Mağduru Acil Yardım İhbar Hattı" 157 numarası, GİGM tarafindan Yabancilar İletişim Merkezi'ne (YIMMER) dönüştürülmüş durumdadır, ancak hâlâ insan ticareti mağdurlarına yönelik ihbar ve yardım hattı işlevini de sürdürmektedir. İlgili uzmanlarla yapılan mülakatlarda belirtildiği üzere, bu geçiş aşamasında başta mağdur tespitinde azalma, koruma hizmetlerinde kurumlararası iş birliği aksaklıkları yaşanmışsa da, gelinen noktada insan ticareti alanında oluşturulan yeni mekanizmalar sağlamlaşmaya başlamıştır. ${ }^{96}$

Yeni mekanizmaların sağlamlaştığına yönelik birkaç gösterge önceki bölümlerde bahsedilen kavramsal ve teorik mevzularla ilişkili olarak şu şekilde özetlenebilir: Öncelikle insan ticaretinin önlenmesi, mağdurların korunması, suçun kovuşturulması ve ulusal/uluslararası iş birliği süreçlerinde devletlerin karşılaştı̆̆ ortak sorunların aşılması için UNODC (a) konuya yönelik bilgi ve araştırma, (b) kapasite arttırma ve geliştirme, (c) denetleme ve değerlendirme alanlarında iyileştirmeler yapılmasını tavsiye etmektedir. ${ }^{97}$ Kurumlar tarafindan güvenilir veri

${ }^{93}$ Uluslararası İş Gücü Kanunu tam metin için bkz. Resmî Gazete No 29800, 2016, http://www.mevzuat.gov.tr/MevzuatMetin/1.5.6735.pdf (Erişim Tarihi: 01.12.2018).

${ }^{94}$ Bkz. YUKK Madde 103-104.

${ }^{95}$ Bkz. YUKK Madde 108.

${ }^{96}$ Mülakatlar 2, 3,4, Aralık 2017, Ankara.

97 "International Framework for Action to Implement the Trafficking in Persons 
Uluslararası İlişkiler ve Uluslararası Göç Bağlamında İnsan Ticareti

toplanmas1, kurumlararası veri paylaşımı, araştırma faaliyetleri yürütülmesi hem insan ticaretinin önlenmesinde hem de mağdurların etkili bir biçimde tespit edilebilmesi ve böylece desteklenebilmesi için önem taşımaktadır. Bu çalışma kapsamında uzmanlarla yapılan görüşmelerde dile getirilen ortak bir sorun, insan ticaretine maruz kalmış birçok kişinin mağdur olduğunun farkında olmadığı ya da çeşitli nedenlerden ötürü bu durumu paylaşmadığ1 yönündedir. Mağdurun tespiti konusu büyük önem taşımakla birlikte, yetkililerce insan ticaretiyle mücadelenin en zorlayıcı aşaması olarak tanımlanmaktadır. Bu durumdan ötürü, insan ticareti mağdurlarının ve onları sömüren kişilerin profillerini incelemek, suçun türleri hakkında kanıta dayalı detaylı veri toplamak, gerekli müdahalenin yapılabilmesi ve etkin önleme stratejileri geliştirilebilmesi için birer ön koşul olarak görülmektedir. ${ }^{98}$ Organize suçlarla mücadele alanında uzman bir yetkiliye göre, özellikle göçmen kaçakçılığı suçu ile karşılaştırıldığında; göçmen kaçakçılığ mağdurlarının insan ticareti mağduru tanımlanmasından çok daha kolay olduğu, insan ticareti mağdurlarının tespiti için kurumların özel çaba sarf etmesi ve etkili bir koordinasyon mekanizması geliştirmesi gerekmektedir. ${ }^{99}$ Buna ek olarak, GÍGM gibi sivil bir kurumun bu alanda yetkilendirilmesiyle birlikte, bu hususlarda daha standart bir sistem oluşturulduğunu vurgulayan görüşmeci, tespit işlemleri esnasında psikolog ve sosyal çalışmacı gibi meslek elemanlarının da sürece dâhil edilmesinin mağdurların desteklenmesi açısından olumlu gelişmeler olduğunu aktarmıştır. ${ }^{100}$

Nitekim GİGM'in resmî mağdur statüsü tanımlama görev ve yetkilerini devralmasıyla birlikte, mağdur tespit sayısında 2013 yıl1 itibariyle önemli bir artış kaydedildiği görülmektedir. GİGM tarafından hazırlanan 2017 İnsan Ticaretiyle Mücadele Y1llı Raporu'nda yer alan verilere göre, 2005-2017 yılları arasında tespit edilen toplam mağdur

Protocol", a.g.y., s. 5.

${ }^{98}$ Mülakatlar 2, 3, 4, 5, Aralık 2017, Ankara.

${ }^{99}$ Mülakat, 4, Aralık 2017, Ankara.

${ }^{100}$ Mülakat, 4, Aralık 2017, Ankara. 
Güvenlik Stratejileri

Cilt: 15

Sayı: 30

sayıs1 1730'dur (bkz. Grafik 1). 2013'te tespit edilen mağdur sayısında dikkat çekici düşüşe rağmen, 2017 itibariyle bu rakam 303'e ulaşmıştır. ${ }^{101}$

\section{Grafik 1: Tespit Edilen İnsan Ticareti Mağduru Sayısı (2005-2017).}

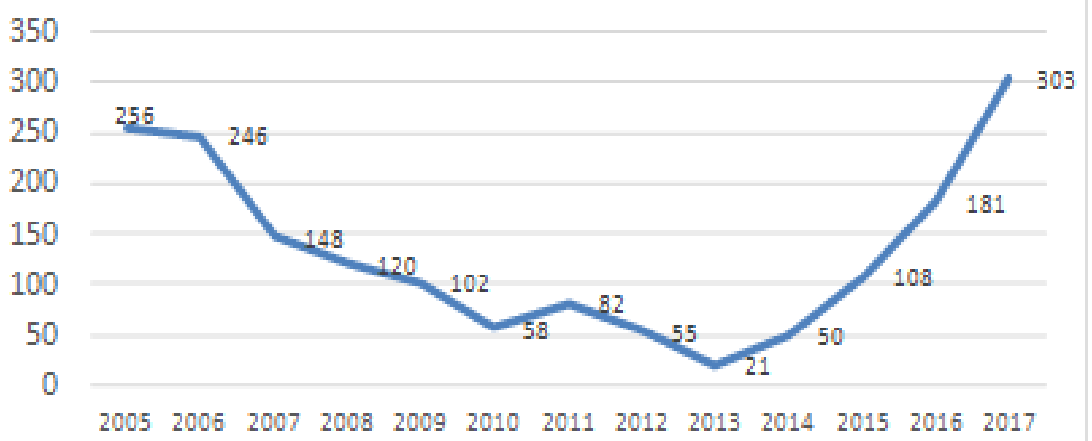

Kaynak: "2017 Türkiye İnsan Ticaretiyle Mücadele Yıllık Raporu”, Göç İdaresi Genel Müdürlüğü

Raporda yer alan veriler sadece tespitlere yönelik rakamsal bir artışa işaret etmemekte, aynı zamanda insan ticaretinin mevcut durum analizi açısından da önemli göstergeler sunmaktadır. Türkiye'nin hızla çeşitlenen göçmen profiliyle birlikte, farklı insan ticareti türlerinin tespitinde artış yaşanmış ve mağdurlarının yaş/cinsiyet dağılımında değişmeler gerçekleşmiştir. ${ }^{102}$ Mağdurların büyük çoğunluğunu fuhuş yapmaya zorlanan kadınlar oluşturmasına rağmen, erkek ve çocuk mağdur sayısının da arttığı görülmektedir. 2014 yılında sadece bir erkek mağdur tespit edilmişken, bu rakam 2017'de 91'e ulaşmıştır. Ayrıca suçun görülme şekilleri bakımından zorla çalıştırma, zorla dilendirme mağduru kişilerin tespitinde de 2013 yllı itibariyle artış olduğu gözlemlenmektedir (bkz. Tablo 3). Raporda 2017 y1lına ait istatistikler incelendiğinde, tespit edilen işgücü istismarı mağdurlarının büyük çoğunluğunun

101 “2017 Türkiye İnsan Ticaretiyle Mücadele Y1llık Raporu”, a.g.y., s. 69.

${ }^{102}$ A.g.y., ss. $67-73$. 
Afganistan ve Fas uyruklu göçmenlerden oluştuğu, zorla dilendirme mağduru kişilerin tümünün ise Suriye uyruklu göçmenlerden oluştuğu görülmektedir. ${ }^{103}$ Verilerde dikkat çeken temel bir husus, 2014 sonrasında tespit edilen insan ticareti mağdurları arasında Suriye uyruklu mağdurların sayısında yaşanan artıştır. ${ }^{104}$ Türkiye, ülkelerinde süregelen savaş nedeniyle kitlesel göçe maruz kalmış yaklaşık 3,6 milyon Suriye uyruklu kişiye geçici koruma kapsamında ev sahipliği yapmaktadır. ${ }^{105}$ Zorunlu göçe maruz kalanların insan ticaretinin farklı türlerine karşı daha korunmasız olduğunun dikkate alındığı ve bundan sonraki aşamalarda Türkiye'nin insan ticaretiyle mücadele stratejisinde bu durumun belirleyici bir rol oynayacağ görüşme gerçekleştirilen uzmanlar tarafından dile getirilmiştir.

Tablo 3: İnsan Ticareti Mağdurlarının İstismar Şekilleri (2005-2017).

\begin{tabular}{|c|c|c|c|c|}
\hline Yıl & $\begin{array}{c}\text { Cinsel } \\
\text { İstismar }\end{array}$ & $\begin{array}{c}\text { İşücï } \\
\text { İstismarı }\end{array}$ & Dilencilik & Toplam \\
\hline Toplam & $\mathbf{1 5 0 4}$ & $\mathbf{1 5 1}$ & $\mathbf{7 5}$ & $\mathbf{1 7 3 0}$ \\
\hline $\mathbf{2 0 0 5}$ & 244 & 12 & - & $\mathbf{2 5 6}$ \\
\hline $\mathbf{2 0 0 6}$ & 239 & 7 & - & $\mathbf{2 4 6}$ \\
\hline $\mathbf{2 0 0 7}$ & 140 & 8 & - & $\mathbf{1 4 8}$ \\
\hline $\mathbf{2 0 0 8}$ & 111 & 8 & 1 & $\mathbf{1 2 0}$ \\
\hline $\mathbf{2 0 0 9}$ & 98 & 4 & - & $\mathbf{1 0 2}$ \\
\hline $\mathbf{2 0 1 0}$ & 57 & 1 & - & $\mathbf{5 8}$ \\
\hline $\mathbf{2 0 1 1}$ & 80 & 2 & - & $\mathbf{8 2}$ \\
\hline $\mathbf{2 0 1 2}$ & 54 & 1 & - & $\mathbf{5 5}$ \\
\hline $\mathbf{2 0 1 3}$ & 21 & - & - & $\mathbf{2 1}$ \\
\hline $\mathbf{2 0 1 4}$ & 43 & 7 & - & $\mathbf{5 0}$ \\
\hline
\end{tabular}

\footnotetext{
${ }^{103}$ A.g.y., s. 72 .

${ }^{104}$ A.g.y., s. 72.

105 Göç İdaresi Genel Müdürlüğü (GİGM) Resmî İnternet Sayfası, "Göç İstatistikleri: Geçici Koruma", http://www.goc.gov.tr/icerik6/gecici-koruma_363_378_4713_icerik (Erişim Tarihi: 12.03. 2019).

${ }^{106}$ Mülakat, 4, Aralık 2017, Ankara.
}

Güvenlik Stratejileri

Cilt: 15

Sayı: 30 
Güvenlik Stratejileri

Cilt: 15

Say1: 30

\begin{tabular}{|l|c|c|c|c|}
\hline $\mathbf{2 0 1 5}$ & 88 & 19 & 1 & $\mathbf{1 0 8}$ \\
\hline $\mathbf{2 0 1 6}$ & 143 & 30 & 8 & $\mathbf{1 8 1}$ \\
\hline $\mathbf{2 0 1 7}$ & 186 & 52 & 65 & $\mathbf{3 0 3}$ \\
\hline
\end{tabular}

Kaynak: "2017 Türkiye İnsan Ticaretiyle Mücadele Yıllık Raporu”,

Göç İdaresi Genel Müdürlüğü

Tablo 4: İnsan Ticareti Mağdurlarının Uyrukları (2005-2017).

\begin{tabular}{|c|c|c|}
\hline Uyruk & Toplam & Oran \\
\hline Toplam & 1730 & $\% 100$ \\
\hline Moldova & 266 & $\% 15$ \\
\hline Kırgızistan & 221 & $\% 13$ \\
\hline Özbekistan & 209 & $\% 12$ \\
\hline Ukrayna & 170 & $\% 10$ \\
\hline Türkmenistan & 147 & $\% 9$ \\
\hline Rusya & 141 & $\% 8$ \\
\hline Suriye & 138 & $\% 8$ \\
\hline Azerbaycan & 107 & $\% 6$ \\
\hline Gürcistan & 91 & $\% 5$ \\
\hline Fas & 52 & $\% 3$ \\
\hline Diğer & 188 & $\% 11$ \\
\hline
\end{tabular}

Kaynak: "2017 Türkiye İnsan Ticaretiyle Mücadele Yıllık Raporu”,

Göç İdaresi Genel Müdürlüğü

Mekanizmaların sağlamlaştı̆ına yönelik bir başka önemli gösterge ise hukuki alanda yapılan düzenlemeler ve bunların insan ticaretiyle mücadelede kapasite geliştirme, denetleme, değerlendirme, mağdurların korunması ve kurumlararası eşgüdüm gibi çeşitli alanlar üzerinde yarattığ1 olumlu etkileridir. Türkiye'nin “Avrupa Konseyi İnsan Ticaretine Karş1 Eylem Sözleşmesi”ni Ocak 2016'da onaylaması ve iç hukuka dâhil etmesiyle birlikte, insan ticaretiyle mücadele süreci ivme kazanmıştır. Bu gelişmeyi takiben 17 Mart 2016 tarihinde "İnsan Ticareti ile Mücadele ve Mağdurların Korunması Hakkında Yönetmelik" "** yürürlüğe girmiştir. ${ }^{107}$

*** Bundan sonra "Yönetmelik" olarak ifade edilecektir. 
Uluslararası İlişkiler ve Uluslararası Göç Bağlamında İnsan Ticareti

Yönetmelik, insan ticareti alanında başlı başına bir kanun olmaması sebebiyle ortaya çıkan temel yasal ve kurumsal boşlukların giderilmesi için önemli bir adım olarak görülmektedir. ${ }^{108}$ Başta mağdur tespiti, mağdur destek hizmetleri (barınma dâhil), gönüllü ve geri dönüş programları, yabancıların ikamet izinlerine ilişkin iş ve işlemleri kapsayan koruma çerçevesi yeniden düzenlenmiştir. ${ }^{109}$ Uzmanlarca ifade edildiği üzere, Yönetmelik mağdurların korunmasında iki temel boşluğu doldurmuştur. Birincisi, mağdur koruma çerçevesinin Türk vatandaşı ve yabancı ayrımı gözetilmeksizin yeniden düzenlenmiş olmasıdır. ${ }^{110}$ Böylece insan ticareti suçunun önlenmesi ve mağdurların korunması çerçevesi hem Türk vatandaşlarının hem yabancıların farklı hassasiyetlerini göz önünde bulunduracak şekilde düzenlenmiştir. İkincisi ise, Yönetmelikte TCK'da yapılan tanıma ek olarak, özellikle çocukların bu suça karşı daha etkin bir şekilde korunmasını sağlamak amacıyla çocuk işçiliği, çocukların suçta kullanılmaları, dilendirilmesi ve evlatlık verilmesi gibi eylemler de insan ticareti suçu kapsamına girebilecek vakalar arasında tanımlanmıştır. ${ }^{111}$

$\mathrm{Bu}$ gelişmelere ek olarak, Protokolde ulusal kapasite geliştirmeye yönelik önemli düzenlemeler yapılmıştır. Öncelikle insan ticareti suçunu önleme ve bu suçla mücadeleye ilişkin politika ve stratejilerin oluşturulması konusunda çalışmalar yürütmek, eylem planı hazırlamak, kamu kurum ve kuruluşları, uluslararası kuruluşlar ile sivil toplum kuruluşları arasında koordinasyonu sağlamak amacıyla insan ticaretiyle mücadelede ve mağdurların korunması alanında ilgili tüm kurumların katılacağı İnsan Ticaretiyle Mücadele Koordinasyon Komisyonu oluşturulmuştur. Yönetmeliğin ulusal iş birliği alanında asıl düzenlediği

\footnotetext{
107 Insan Ticaretiyle Mücadele ve Mağdurların Korunması Hakkında Yönetmelik tam metin için bkz. Resmî Gazete No 29656, 2016, http://www.resmigazete.gov.tr/ eskiler/2016/03/20160317-9.htm (Erişim Tarihi: 01.12.2018).

${ }^{108}$ Mülakat, 1, 2, 3, 4, 5 Aralık 2017, Ankara.

${ }^{109}$ Yönetmelik, Madde 1; Madde 3.

${ }^{110}$ Mülakat, 3, 4, Aralık 2017, Ankara.

${ }^{111}$ Yönetmelik, Madde 17(1).
}

\section{1}

Güvenlik Stratejileri

Cilt: 15

Say1: 30 
alan Ulusal Yönlendirme Mekanizması olmuştur. Görüşme gerçekleştirilen bir uzman, insan ticaretiyle mücadele stratejisinin insan güvenliği odaklı bir yapıda geliştirilmesi için etkin ve sistematik bir ulusal yönlendirme mekanizması oluşturulmasına uzun süredir ihtiyaç duyulduğunu ifade etmiştir. ${ }^{112}$ Özellikle de insan ticareti mağduru olabileceğinden şüphe duyduğu kişilerle iş yaşamında sık karşılaşan sağlık personeli gibi yetkililerin mağdurları nereye yönlendirmesi ve nasıl destek olması gerektiği hususunda uzun süredir bir bilgi eksikliği sorunu yaşandığını belirtmiştir. Ulusal Yönlendirme Mekanizması devlet kurumlarının, sivil toplum ile stratejik iş birliği içinde, insan ticareti mağdurlarının insan haklarını koruma ve geliştirme yükümlülüklerini yerine getirmeye yönelik çabaları koordine ettiği bir iş birliği çerçevesi olarak tanımlanmaktadır. ${ }^{113}$

UNODC Eylem Çerçevesi'nde de insan ticareti mağdurlarının korunması ve desteklenmesi için ulusal yönlendirme mekanizmalarının oluşturulması ve güçlendirilmesi vurgusu yapılmaktadır. ${ }^{114} \mathrm{Bu}$ bağlamda Yönetmelik insan ticareti mağduruyla karşılaşan her şahsa ihbar edebileceği yetkili kurumlardan, mağdurların ilk tespit edilme aşamasından, kolluk tarafından yürütülen değerlendirme, operasyon ve adli prosedür süreçlerinden, mağdur tanımlamanın GIGG ve savcılık tarafindan yürütüldüğü idari ve adli boyutlarından, mağdur tanımlanma süreci tamamlandıktan sonra sağlanacak koruma ve destek programlarında hangi kurumların ne gibi sorumluluk ve yükümlülükleri olduğuna kadar geçen bütün süreci netleştirmiştir (Bkz. Şekil 1). Böylece, mağdurların etkin bir şekilde korunmasını sağlamak için kurumların birbirleriyle etkin bir biçimde iletişimde ve eşgüdümde olduğu yönlendirme mekanizmasının zemini oluşturulmuştur.

${ }^{112}$ Mülakat 5, Aralık 2017, Ankara.

113 "National Referral Mechanisms: Joining Efforts to Protect the Rights of Trafficked Persons, A Practical Handbook", OSCE/ODIHR, Warsaw, 2004, s. 15, https://www.osce. org/odihr/13967?download=true (Erişim Tarihi: 01.12.2018).

114 "International Framework for Action to Implement the Trafficking in Persons Protocol", a.g.y., s. 45. 
Şekil 1: İnsan Ticaretiyle Mücadelede Ulusal Yönlendirme Mekanizması (UYM).

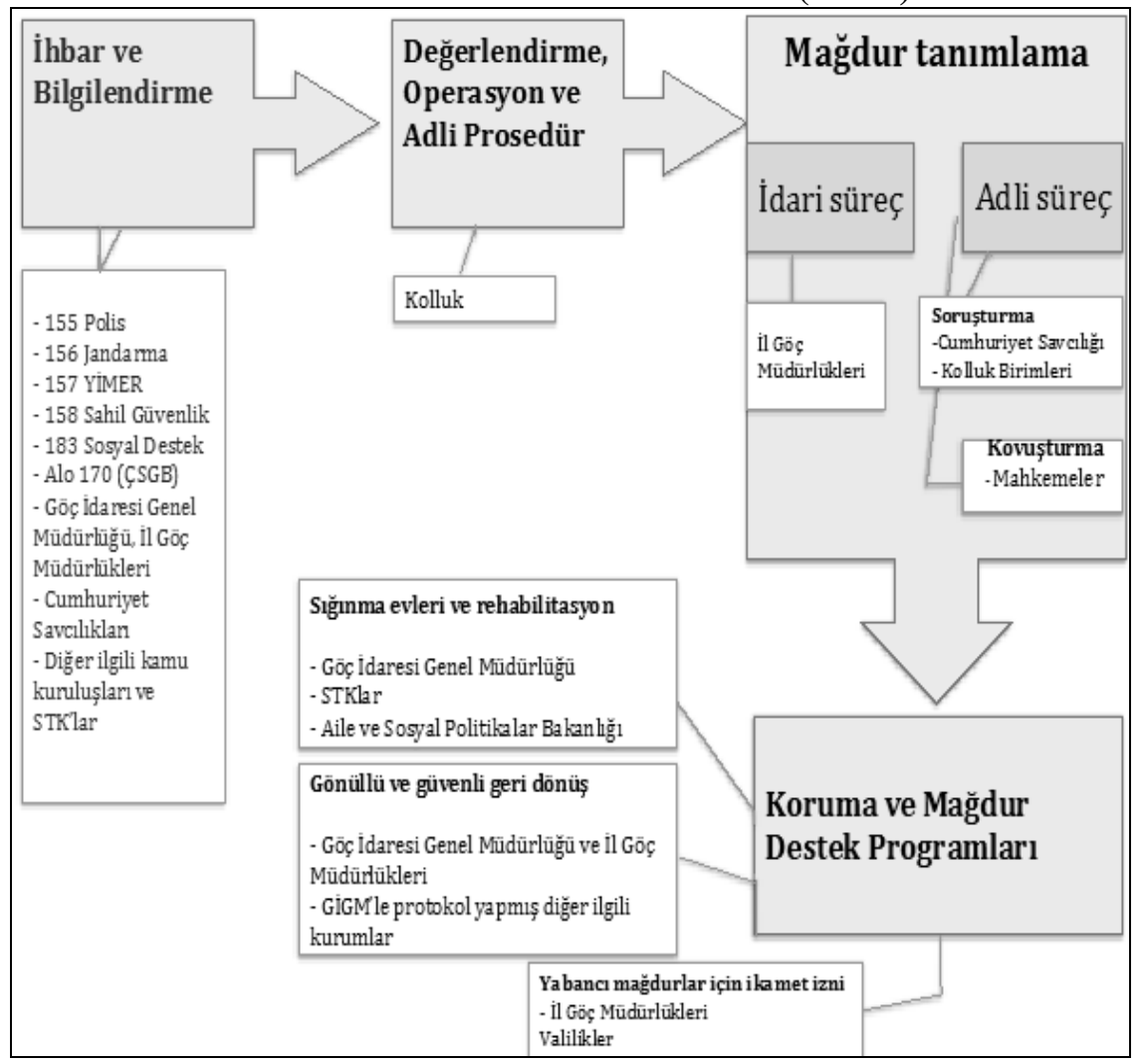

Kaynak: Yazar tarafindan İnsan Ticaretiyle Mücadele ve Mağdurların Korunması Hakkında Yönetmelik’ten uyarlanarak hazırlanmıştır.

Kapasite geliştirme ve arttırma alanında yaşanan bir başka gelişme ise, GİGM dışında diğer ilgili kurumların da insan ticaretiyle mücadele alanında uzmanlaşmış birimler ve kadrolar oluşturmasıdır. Başta Emniyet Genel Müdürlüğü (EGM), Jandarma Genel Komutanlı̆̆ı, Sahil Güvenlik Komutanlığ 1 olmak üzere, kolluk kuvvet birimleri insan ticaretiyle mücadelenin başlıca aktörleri konumundadır. Merkezî ve yerel kolluk

\section{3}

Güvenlik Stratejileri

Cilt: 15

Sayı: 30 
274

Güvenlik Stratejileri

Cilt: 15

Sayı: 30

kuvvet birimleri, insan ticareti mağdurlarının ilk tespit süreci, ardından idari ve hukuki usullerin tamamlanması için ilgili otoritelere yönlendirilmesi gibi kilit bir rol üstlenmektedir. $\mathrm{Bu}$ kurumların bünyesinde 2016 yılında Göçmen Kaçakçılı̆̆ı ve İnsan Ticareti ile Mücadele Daire Başkanlık birimleri kurulmuştur. Önceki uygulamalarda organize suçlar birimi altında değerlendirilen göçmen kaçakçılığı ve insan ticareti, yetkililerin birden fazla konuyla ilgilenmelerini gerektirmiş; insan ticareti ve göçmen kaçakçılığı gibi teknik bilgi donanımı, suçla mücadelede ön araştırma ve istihbarat çalışması gerektiren alanlarda uzmanlaşmalarını zorlaştırmıştır. Salt göçmen kaçakçılığ 1 ve insan ticaretine yoğunlaşmış birimlerin oluşturulmasının mücadele faaliyetlerinin, istihbarat toplamadan diğer kurumlarla bilgi alışverişine kadar her alanda yetkilileri daha etkin kılması açısından olumlu bir gelişme olduğu, ayrıca bu alanda uzman personel yetişmesi için de bir firsat sunduğu alanda uzman kişilerce dile getirilmiştir.

Çalışmanın önceki bölümlerinde de değinildiği üzere, iş birliği insan ticareti suçunun önlenmesi ve bu suçla etkili bir mücadele geliştirilebilmesi için en temel hususlardan biri olarak kabul edilmektedir. UNODC Eylem Planı'nda taraf devletlere iş birliğinin ulusal ve uluslararası olmak üzere iki düzeyde geliştirilmesi tavsiye edilmektedir. ${ }^{115}$ İnsan Ticaretiyle Mücadele Koordinasyon Komisyonu, Ulusal Yönlendirme Mekanizması gibi ulusal düzeyde kurumlararası iş birliğini geliştirmek amaçlı oluşturulan yeni mekanizmalardan yukarıda bahsedilmiştir. İnsan ticaretiyle mücadele alanında iş birliğinin nasıl bir yapıda olması gerektiğine yönelik teorik yaklaşımlar ve iyi uygulama örnekleri göz önünde bulundurulduğunda, Türkiye'de sivil toplum ve özel sektör aktörlerinin insan ticaretiyle mücadele alanına henüz yaygın bir şekilde dâhil olmadığ 1 gözlemlenmektedir.

İnsan ticareti alanında uzman bir sivil toplum çalışanı, sivil toplum örgütlerinin birçok Avrupa ülkesinde insan ticaretine yönelik

115 "International Framework for Action to Implement the Trafficking in Persons Protocol", a.g.y., ss. 45-8. 
farkındalık faaliyetleri yürütülmesinde ve mağdurlara destek hizmetleri sağlanmasında aktif olduğunu, sorumlulukları zaman zaman tek başlarına üstlendiğini ya da devlet kurumlarıyla iş birliği çerçevesinde yürüttüklerini ifade etmiştir. ${ }^{116} \mathrm{Bu}$ duruma bir örnek olarak, Avrupa'da insan ticaretiyle mücadele alanında çalışan sivil toplum örgütlerinin oluşturduğu La Strada gibi uluslararası platformların gündem belirlemede,

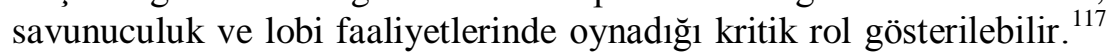
Sivil toplum örgütlerinin daha hızlı bir şekilde harekete geçme, daha geniş kitlelere ulaşabilme, hem resmî, hem gayri resmî mekanizmalar aracılığıla mağdurlara yardım edebilmede daha avantajlı olduğu belirtilmiştir. ${ }^{118}$ Ancak bu duruma karş1lı, Türkiye'de insan ticareti alanında faaliyet gösteren sivil toplum örgütleri henüz oldukça sınırlı sayıdadır. ${ }^{119} \mathrm{Bu}$ duruma sebep olan başlıca etkenler, Türkiye'de insan ticareti alanında uzun süredir aktif olan Aile Danışmanları Derneği tarafindan hazırlanan bir çalışmada şu şekilde özetlenmiştir: İnsan ticaretinin teknik bilgi ve finansal kaynak gerektiren bir alan olmas1; sivil toplum örgütleri tarafinca insan ticareti alanında bilgi ve farkındalık eksikliği; hizmet vermeye gönüllü kuruluşların ise faaliyetleri yürütmek ve profesyonel meslek elemanları istihdam edebilmek için insan gücü ve finansal kapasitelerinin arttırılmasına ihtiyaç duymalarıdır. ${ }^{120}$

\footnotetext{
${ }^{116}$ Mülakat 5, Aralık 2017, Ankara.

${ }^{117}$ Daha fazla bilgi için bkz. La Strada European Network Against Trafficking in Human Beings Resmî İnternet Sayfas1, http://lastradainternational.org (Erişim Tarihi: 01.12.2018)

${ }^{118}$ Mülakat 5, Aralık 2017, Ankara.

119 Türkiye'de insan ticaretiyle mücadele alanında uzun süredir faaliyet gösteren ve devlet kurumlarıyla yakın iş birliği içinde çalışan iki başlıca sivil toplum örgütü İnsan Kaynağını Geliştirme Vakfı (IKGV) ve Aile Danışmanları Derneği'dir. Daha fazla bilgi için bkz. http://www.ikgv.org/; http://ailedanismanlari.org (Erişim Tarihi: 01.12.2018). Sivil toplum örgütlerinin bu alanda yürüttükleri çalışmalar için, ayrıca bkz. "2017 Türkiye İnsan Ticaretiyle Mücadele Yıllık Raporu", a.g.y., ss. 58-59.

120 "The Power of Civil Society to Combat Human Trafficking", Aile Danışmanları Derneği, 2017, https://ailedanismanlari.org/human-trafficking/the-power-of-civil-societyto-combat-human-trafficking-project-nongovernmental-organizations-sop-standardoperational-procedures/ (Erişim Tarihi: 01.12.2018)
}

\section{5}

Güvenlik Stratejileri

Cilt: 15

Sayı: 30 
Diğer taraftan, yine uluslararası örnekler incelendiğinde özel

Güvenlik Stratejileri

Cilt: 15

Sayı: 30 sektörün giderek artan bir biçimde insan ticaretiyle mücadele alanında aktif rol oynadığ1 görülmektedir. Buna Microsoft, Coca Cola, Hilton Otelleri, Ford gibi çokuluslu şirketlerin oluşturduğu "Global Business Coalition Against Human Trafficking" adlı uluslararası platform örnek gösterilebilir. ${ }^{121}$ Özel sektörle iş birliğinin, özellikle tedarik zincirlerinde zorla çalıştırmanın önlenmesi için gerekli olduğu ifade edilmektedir. ${ }^{122}$ Ayrıca özel sektör temsilcilerinin, meslek, ticaret ve sanayi odalarının insan ticareti suçunun önlenmesine yönelik işverenlerin bilinçlendirilmesinde ve toplumsal farkındalık arttırıcı çalışmalarda daha öncül rol oynaması gerektiği uzmanlar tarafindan vurgulanmıştır. ${ }^{123}$

Türkiye'nin uluslararası düzeyde iș birliği çalışmalarının da yeni gelişmeler çerçevesinde yoğunlaştığ 1 gözlenmektedir. GİGM İnsan Ticareti Faaliyet Raporu'nda belirtildiği üzere, 2017 yılı sonu itibariyle Belarus, Gürcistan, Ukrayna, Moldova, Kırgızistan olmak üzere beş ülke ile insan ticaretiyle mücadele iş birliği anlaşması yapılmış, 100 'den fazla ülke ile de düzensiz göç ve insan ticareti alanında iş birliğine yönelik maddeler içeren güvenlik iş birliği anlaşması yapılmıştır. ${ }^{124}$ İnsan ticaretiyle mücadele alanında aktif olarak görev yapan yetkililer, bu tür işbirlikleri çerçevesinde özellikle kendi uzmanlık alanlarında başka ülkelerden paydaş uzmanlarla bir araya geldikleri platformların mesleki açıdan katkılarını vurgulamış, gerçekleşen fikir alışverişlerinin, diğer ülke uygulamalarının anlaşılmasının hizmetlerin iyileştirilmesindeki önemine değinmişlerdir. ${ }^{125} \mathrm{Bu}$ gelişmelere ek olarak, GİGM'in Uluslararası Göç Örgütü (IOM) ve Uluslararası Göç Politikaları Araştırma Merkezi (ICMPD) gibi insan ticareti alanında uzmanlaşmış uluslararası kuruşlarla yakın iş birliği

${ }^{121}$ Global Business Coalition Against Human Trafficking hakkında detaylı bilgi için bkz. https://www.gbcat.org/\#about (Erişim Tarihi: 01.12.2018)

${ }^{122}$ Mülakat 5, Aralık 2017, Ankara.

${ }^{123}$ Mülakat 2, 5, Aralık 2017, Ankara.

124 “2017 Türkiye İnsan Ticaretiyle Mücadele Y1llık Raporu”, a.g.y., s. 57.

${ }^{125}$ Mülakat 1, 2, 3, 4, Aralık 2017, Ankara. 
mekanizmaları oluşturduğu, ulusal ve uluslararası ortak projeler yürüttüğü görülmektedir. ${ }^{126} \mathrm{Bu}$ tür projeler kamu görevlileri, sivil toplum temsilcileri, medya çalışanlarına yönelik kapasite geliştirme, eğitim ve farkındalık çalışmaları, kamuoyunu bilgilendirme faaliyetleri gibi alanları kapsamaktadır. ${ }^{127}$ İlgili uzmanlar, bu tür faaliyetlerin özellikle insan ticaretinin nispeten daha az bilinen ve daha az tespit edilen zorla çalıştırma, zorla dilendirme ve zorla evlendirme gibi türlerine yönelik farkındalığı arttırdığını ifade etmiştir.

\section{Sonuç}

Uluslararası ölçekte insan ticareti, sınıraşan örgütlü suçlar ve düzensiz göçün önemli bir bileşeni olarak, 21. yüzyılın başlıca küresel sorunlarından biri haline gelmiştir. Günümüzde sıklıkla modern kölelik olarak tasvir edilen insan ticareti, insanlığa karşı işlenen bir suç olarak kabul edilmektedir. Özellikle 1990'lardan itibaren insan ticaretinin yeni rotalarda, çeşitlenen istismar türleri ve mağdur profilleriyle sürekli olarak artmaya devam etmesi, konunun uluslararası boyutunun ön plana çıkmasına yol açmıştır. 2003 yılında yürürlüğe giren Sınıraşan Örgütlü Suçlara Karşı BM Sözleşmesi'ne ek protokolle insan ticaretinin uluslararası hukuk kapsamında tanımının yapılmas1 ve bunu takiben taraf devletlerin büyük bir kısmının insan ticaretini iç mevzuatlarında suç kapsamına almış olması, konuyla küresel alanda mücadele açısından bir dönüm noktası olarak değerlendirilmektedir. Bu çalışmada da ortaya koyulduğu gibi insan ticaretiyle mücadele uluslararası politika gündeminde giderek daha önemli bir yer tutmaktadır. Ancak yine görülmektedir ki, sorunla mücadelede uluslararası iş birliğine yapılan vurgu ile mücadelenin uygulamadaki etkinliği orantılı değildir. Bunun en temel göstergesi ise, resmî kurumlarca tespit edilen ve koruma altına alınan mağdur sayısının, dünya genelindeki tahminlerin çok gerisinde kalmasıdır. Bu çalışmada vurgulanan bir husus, soruna

\footnotetext{
${ }^{126}$ Uluslararası kuruluşlarla yürütülen proje detayları için bkz. "2017 Türkiye İnsan Ticaretiyle Mücadele Yıllık Raporu", a.g.y., ss. 29-30.

${ }^{127}$ Mülakat 2,3, Aralık 2017, Ankara.
}

\section{7}

Güvenlik Stratejileri

Cilt: 15

Say1: 30 
yönelik etkin mücadele stratejileri geliştirilebilmesi için öncelikle insan ticaretine ilişkin süregelen kavramsal ve teorik tartışmaların anlaşılması

Güvenlik Stratejileri

Cilt: 15

Sayı: 30 gerektiğidir. Bu bağlamda değerlendirilmesi gereken sonuçlar, insan ticaretine yönelik etkili bir mücadelenin öncelikle konunun küresel ölçeğini yansitan verilerin tahminler yerine daha sistematik yöntemlerle hesaplanması gerektiği, böylece insan ticaretinin daha az gözlemlenebilir türlerinin de ancak bu şekilde kapsamlı bir şekilde irdelenebileceği yönündedir. Ayrıca hukuki tanımlara ve olgular arasındaki temel farklılıklara rağmen, insan ticaretinin sürekli olarak değişen göç ve iltica dinamikleri çerçevesinde yeni mağdur grupları ortaya çıkarttı̆̆ dikkate alınmalıdır. Nitekim çalışmanın birinci bölümünde göçmen kaçakçıllı̆ında da göçmenlerin mağdur duruma düşebildiği, insan ticareti unsurları içeren bir durumla karşı karşıya kalabildiğinden bahsedilmiştir. Düzenli ve güvenli göç kanallarının sınırlı olması, uluslararası koruma sisteminin yetersizlikleri nedeniyle sığınmacıların da düzensiz göç yollarına sıklıkla mecbur kalması, göçmen kaçakçılığ 1 ve insan ticareti şebekelerinin düzensiz göçmenlerin hassasiyetlerini istismar etmesi gibi birçok sorunu da beraberinde getirmektedir.

Teorik tartışmalarda dikkat çeken başlıca mevzu ise, insan ticareti olgusunun tam olarak kuramlaştırılmamış ve parçalanmış olmasıdır. İnsan ticaretini uluslararası göç kuramları bağlamında inceleyen çalışmaların büyük bir kısmı, insan ticareti ve göçmen kadınların mağduriyeti arasındaki bağlantıya odaklanmakta, bir kısmı da özellikle hedef ülke konumundaki ülkelerin göç politikaları kapsamında insan ticaretine nasıl yaklaştığını analiz etmektedir. İnsan ticaretinin çoğu hedef ülke tarafindan düzensiz/yasadışı göçle eş değer görülmesi ve ulusal güvenliğe yönelik bir tehdit olarak algılanması, insan ticareti mağdurlarının yeterli düzeyde korunamamasına ve zaman zaman düzensiz göçmenlere uygulanan sınırdışı etme politikalarına maruz kalmalarına yol açmaktadır. Uluslararası ilişkiler disiplini kapsamında teorik tartışmalar ise insan ticaretini devletlerin güvenliğine yönelik bir tehdit olarak ele alan geleneksel güvenlik yaklaşımı ve insan ticaretini bir insan güvenliği meselesi olarak irdeleyen genişletilmiş güvenlik yaklaşımı çerçevesinde şekillenmiştir. Ancak insan ticaretinin sadece devlete yönelik bir tehdit olarak kuramlaştırılması, insan ticareti 
mağdurlarının devletlerin korumakla yükümlü olduğu bireysel hak ve özgürlüklerinin göz ardı edilmesi; bu tür sınıraşan bir sorunla mücadelede uluslararası düzeyde iş birliğine yeterli önemin gösterilmemesi gibi sorunları da beraberinde getirmektedir. İnsan ticaretini insan güvenliğine bir tehdit olarak kuramlaştıran feminizm, eleştirel teori gibi yaklaşımlar ise hem toplumlar, hem mağdurlar açısından daha kapsamlı analizler sunmaktadır. Bu durumdan çıkartılabilecek önemli bir sonuç, insan ticaretine salt devlet odaklı bir güvenlik perspektifinden yaklaşmak yerine, olgunun insan güvenliğini ön plana çıkartan yaklaşımlar çerçevesinde kavramlaştırılması ve kuramlaştırılması yönündedir. Böylece hem mağdurları hedef alan çeşitli tehdit türlerinin analiz edilmesi, mağdurlara daha etkin bir koruma ve destekleme çerçevesi sunulabilmesi, hem de düzensiz göçmenler gibi insan ticareti açısından kırılgan olan gruplara yönelik koruma çerçevesinin güçlendirilmesi sağlanabilir. Ayrıca, sorunla mücadelede yönetişim kavramına vurgu yapan çalışmalar devletlerin insan ticareti gibi sınıraşan ancak özünde insan güvenliğini ilgilendiren bir sorunla mücadelede ne tür uluslararası iş birliği mekanizmaları geliştirmesi gerektiğini, uluslararası kuruluşlar, sivil toplum ve özel sektör aktörleri gibi devlet olmayan aktörlerin de bu mekanizmalara neden dâhil edilmesi gerektiği gibi hususların anlaşılmasına katkıda bulunmaktadır.

Çalışmanın son bölümünde, Türkiye'de insan ticareti alanının göç yönetim yapısına entegre edilmesiyle gerçekleşen güncel gelişmeler değerlendirilmiştir. Değerlendirmeyi nitel verilerle desteklemek amacıyla Türkiye'de insan ticaretiyle mücadele alanında uzman beş kişiyle Aralık 2017'de gerçekleştirilen derinlemesine mülakatlardan bulgulara yer verilmiş, ortak noktalar birleştirilerek analiz edilmiştir. Türkiye'de insan ticaretiyle mücadele ulusal çerçevesi, bu alanda uluslararası standartların oluşumunu takiben 2000'li yılların başından itibaren hızla gelişmeye devam etmektedir. Henüz insan ticareti ile mücadeleye özel bir kanun bulunmamasına rağmen, son yıllarda göç politikalarının revize edilmesi, insan ticaretiyle mücadele alanının da uluslararası standartlara uygun ve kapsayıcı bir şekilde yeniden yapılandırılmasını mümkün kılmıştır. İnsan ticaretiyle mücadele alanında uluslararası normların oluşması Türkiye' de de ilgili çevreler 
280

Güvenlik Stratejileri

Cilt: 15

Sayı: 30

arasında konuya yönelik bir farkındalık yaratmıştır. Mülakatlardan elde edilen önemli bir bulgu ise, özellikle 2010 yılı sonrasında ilgili karar alıcıların insan ticaretiyle mücadele alanının daha içselleştirildiği bir dönem başladığı ve bunun da uluslararası normların ulusal düzeyde daha güçlü bir siyasi irade ile uygulanmasını mümkün kıldığı olmuştur. Bir başka deyişle, insan ticaretiyle mücadele, sadece dişsal faktörlerin etkisiyle düzenlemeler yapılan bir alan olmaktan çıkmış, Türkiye'nin kendi göç yönetim reform süreci için de bir gereksinim haline gelmiştir.

2013 yılında Yabancılar ve Uluslararası Koruma Kanunu'nun yürürlüğe girmesiyle birlikte, Göç İdaresi Genel Müdürlüğü gibi sivil bir kurumun insan ticaretiyle mücadele alanında yetkili kılınması, oluşturulan yeni mekanizmaların ve politikaların, insan güvenliği ve mağdur odaklı bir çerçevede gelişmesine zemin hazırlamıştır. Uzmanlarla gerçekleştirilen mülakatların ortak bulgularından biri, GİGM'in, insan ticareti alanında araştırma, veri toplama, veri paylaşımı, ulusal yönlendirme mekanizması, kurumlararası eşgüdüm, mağdur tespit ve koruma süreçleri gibi çeşitli alanlarda standart bir sistem geliştirilmesine olumlu katkılarının olduğudur. Buna ek olarak, Avrupa Konseyi İnsan Ticaretine Karşı Eylem Sözleşmesi'nin onaylanması ve iç hukuka dâhil edilmesi ve ardından da İnsan Ticareti ile Mücadele ve Mağdurların Korunması Hakkında Yönetmeliğin yürürlüğe girmesi ile insan ticaretiyle mücadele süreci yeni bir ivme kazanmıştır. Bu Yönetmelikle, insan ticareti alanında başlı başına bir kanun olmaması sebebiyle ortaya çıkan -ve özellikle de insan ticareti suçunun önlenmesi ve mağdur koruma çerçevesini etkileyen- temel yasal ve kurumsal boşlukların giderilmesi için önemli bir adım atılmıştır. Başta mağdur koruma çerçevesinin Türk vatandaşı ve yabancı ayrımı gözetilmeksizin geliştirilmiş olması, yabancı mağdurlara yönelik ikamet izni, destek hizmetleri ve gönüllü geri dönüş programları gibi alanların yeniden düzenlemiş olması olumlu gelişmeler olarak öne çıkmaktadır. Ve yine aynı Yönetmelikte TCK'da yapılan tanıma ek olarak, çocuk işçiliği, çocukların suçta kullanılmaları, dilendirilmesi ve evlatlık verilmesi gibi eylemler de insan ticareti suçu kapsamına girebilecek vakalar arasında tanımlanmıştır.

$\mathrm{Bu}$ çalışmada da ortaya koyulduğu üzere, insan ticareti suçunun önlenmesi ve bu suçla etkili bir mücadele geliştirilebilmesinde ulusal 
ve uluslararası düzeyde iş birliği kilit bir rol oynamaktadır. Nitekim uluslararası işbirliklerinin geliştirilmesi mevzusu hem BM 2030 Sürdürülebilir Kalkınma Gündemi kapsamında hem de Küresel Göç Mutabakatı müzakere süreçlerinde dikkate alınmıştır. Görüşme gerçekleştirilen uzmanlar Türkiye'de de insan ticaretiyle mücadele alanında ulusal ve uluslararası düzeyde işbirliklerinin ilerlemekte olduğuna dikkat çekmiş, İnsan Ticaretiyle Mücadele Koordinasyon Komisyonu gibi yeni oluşturulan mekanizmaların önemini vurgulamışırır. Yönetmelikle birlikte netlik kazanan Ulusal Yönlendirme Mekanizma çerçevesi de devlet kurumları ile sivil toplumun insan ticaretiyle mücadele alanında iş birliği geliştirmesine fursat sunmaktadır. $\mathrm{Bu}$ bağlamda dünyadaki iyi uygulama örnekleri ile karşılaştırıldığında, Türkiye örneğinde iyileştirmeye açık bir alan devlet dışı aktörlerin karar alma ve uygulama süreçlerine katılımlarıdır. Bu noktada özellikle sivil toplum kuruluşlarının ve özel sektörün insan ticaretiyle mücadele alanında daha etkin rol oynaması Türkiye'nin insan ticaretiyle mücadele çerçevesinin daha da kapsamlı bir şekilde geliştirmesine katkıda bulunacaktır.

\section{Summary}

International human trafficking has become one of the most critical global challenges of the 21 st century, mainly owing to the increasing and diversified mixed migration flows throughout the world. While human trafficking takes place also within national borders, its international dimension has become more prominent due to the changing structures and conditions of the post-Cold War period, grabbing wider global attention. Nonetheless, the growing interest shown by governments, international organizations, the public, and the media in the fight against human trafficking at times overshadows academic debates that attempt to provide an understanding of the concept based on factual and theoretical evidence. Accordingly, one of the main objectives of this study is to overview the main conceptual and theoretical debates on human trafficking within the scope of international relations and international migration in an attempt to emphasize their significance in developing effective anti-trafficking strategies. 
282

Güvenlik Stratejileri

Cilt: 15

Sayı: 30

Among other conceptual issues, the first part of the paper examines the blurred relationship between human trafficking, migrant smuggling, and irregular migration. Limited availability of regular and safe migration channels and the shortcomings of the international protection system are among factors compelling many migrants/asylum seekers to take irregular migration routes mostly with the help of migrant smugglers. Various vulnerabilities of irregular migrants often make them easy targets of human trafficking networks. Thus, human trafficking is not a fixed phenomenon, constantly adapting itself to the changing dynamics of migration and asylum. It appears that theoretical accounts that perceive human trafficking as a human security issue, such as feminist theory and critical theory, are able to capture its implications on society and individuals more comprehensively. All in all, this study suggests that conceptualizing and theorizing human trafficking from a human security-oriented perspective would contribute to (1) the development of a more comprehensive protection framework both for victims as well as other vulnerable groups and (2) the creation of an effective international cooperation mechanism in the fight against human trafficking.

The final part assesses recent anti-trafficking legislative and institutional developments in Turkey, which have continuously developed since the early 2000s. A recent reform process of migration policies has enabled the restructuring of anti-trafficking policies in line with the international standards. This discussion is complemented with findings from in-depth interviews conducted with five human trafficking experts working at national public bodies, international and non-governmental organizations. The purpose of conducting semi-structured interviews was to understand and assess individual perspectives and perceptions of actors who are actively involved in policy-making, policy development, and policy implementation in the field of human trafficking. In this context, since the adoption of the Law on Foreigners and International Protection in 2013 and the establishment of Directorate General of Migration Management (DGMM), a number of legal and institutional arrangements have been undertaken. As the new national coordinator of the anti-trafficking field, the DGMM has developed a standardized system in various areas, including research, data collection, data 
Uluslararası İlişkiler ve Uluslararası Göç Bağlamında İnsan Ticareti

sharing, national referral mechanism, inter-agency coordination, victim 283 identification, and protection processes. Accordingly, one of the main findings of the study is that newly formed mechanisms and policies seem to have paved the way for the development of a human securitysensitive and a victim-oriented anti-trafficking framework. The final part of the study intends to draw attention to the newly adopted Regulation on the Protection of Human Trafficking and the Protection of Victims, which expands the victim protection framework and introduces improvements in coordination mechanisms. Finally, in parallel with the conceptual and theoretical debates, the study concludes by underlining the key role of cooperation both at national and international levels -also providing examples from recent developments in Turkeyin preventing the crime of human trafficking and in developing effective anti-trafficking strategies.

\section{KAYNAKÇA}

\section{Kitaplar}

ATASÜ-TOPÇUOĞLU, Reyhan, Ideology and the Fight Against Human Trafficking, Routledge, New York, 2014.

BETTS, Alexander (ed.), Global Migration Governance, Oxford University Press, New York, 2011.

BRYSK, Alison ve Austin Choi-Fitzpatrick, Austin, From Human Trafficking to Human Rights: Reframing Contemporary Slavery, University of Pennsylvania Press, Philadelphia, 2012.

BUZAN, Barry, Waever, Ole, ve Wilde de, Jaap, Security: A New Framework for Analysis, Lynne Rienner Publishers, Boulder, 1998.

CRAWFORD, Mary, Sex Trafficking in South Asia: Telling Maya's Story, Routledge, New York, 2010.

DAİGLE, Leah E. ve Muftic, Lisa R., Victimology, Sage Publications, United States of America, 2016.

DALLA, Rochelle L. Lynda M. Barker, John DeFrain, ve Cella Williamson (ed.), Global Perspectives on Prostitution and Sex Trafficking, Lexington Books, Maryland, 2013.

DERKS, Annuska, Combating Trafficking in South East Asia, A Review of Policy and Programme Responses, International Organization for Migration, 2000.

KYLE, David. and Rey Koslowski (ed.), Global Human Smuggling: Comparative Perspectives, Johns Hopkins University Press, Baltimore, 2001.

LOCHER, Birgit, Trafficking in Women in the European Union, Springer Publications, Wiesbaden, 2007. 


\author{
Fulya MEMIŞOĞLU
}

\section{4}

Güvenlik Stratejileri

Cilt: 15

Sayı: 30

OKUBO, Shiro ve Shelley, Louise, Human Security, Transnational Crime and Human Trafficking: Asian and Western Perspectives, Routledge, New York, 2011.

SHELLEY, Louise, Human Trafficking, A Global Perspective, Cambridge University Press, Cambridge, 2010.

TRIANDAFYLLIDOU, Anna, Irregular Migration in Europe: Myths and Realities, Taylor and Francis, London, 2010.

\title{
Kitap Bölümleri
}

BEARE, Margaret E., "Illegal Migration: Personal Tragedies, Social Problems, or National Security Threats?", P. Williams (ed.), Illegal Immigration and Commercial Sex: The New Slave Trade, Frank Cass, London, 1999, ss. 11-41.

Dİ NICOLA, Andrea, "Researching int Human Trafficking: Issues and Problems", M. Lee (ed.), Human Trafficking, Routledge, New York, 2007, ss. 63-86.

JOHNSSON, Ann, "Introduction: Human Trafficking and Human Security in the Baltic Sea Region", Ann Johnsson (ed.), Human Trafficking and Human Security, Routledge, New York, 2009, ss. 15- 23.

KELLY, Liz, "You Can Find Anything You Want: A Critical Reflection on Research on Trafficking in Persons within and into Europe", Data and Research on Human Trafficking: A Global Survey, International Organization for Migration, 2005, ss. 235-265.

KOSER, Khalid, "The smuggling of Refugees”, D. Kyle ve R. Koslowski (ed.), Global Human Smuggling: Comparative Perspectives, Johns Hopkins University Press, Baltimore, 2001, ss. 256-272.

LEE, Maggy, "Introduction: Understanding Human Trafficking" M. Lee (ed.), Human Trafficking, Routledge, New York, 2007, ss. 15- 39.

PİCARELLİ, John T., "Historical Approaches to the Trade in Human Beings", M. Lee der., Human Trafficking, Routledge, New York, 2007, ss. 40-62.

WONG, Diana, "The rumor of trafficking: border controls, illegal migration, and the sovereignty of the nation-state", W. van Schendel ve I. Abraham der., Illicit Flows and Criminal Things: States, Borders, and the Other Side of Globalization, Indiana University Press, Bloomington, 2005, ss. 69-100.

JACQUI True, "Feminism", Scott Burchill (ed.), Theories of International Relations, Palgrave MacMillan, New York, ss. 231-76.

\section{Makaleler}

BALES, Kevin, "What Predicts Human Trafficking?", International Journal of Comparative and Applied Criminal Justice, 2007, Cilt 31, No 2, ss. 269-79.

DE HEREDIA, Marta Iniguez, "People Trafficking: Conceptual issues with the United Nations Trafficking Protocol 2000", Human Rights Review, 2008, Cilt 9, № 3, ss. 299-316. EMMERS, Ralf, "Globalization and Non- Traditional Security Issues: A Study of Human and Drug Trafficking in East Asia", RSIS Working Paper, 2004, No. 62, ss.1-26.

FRIESENDORF, Cornelius, "Pathologies of Security Governance: Efforts Against Human Trafficking in Europe", Security Dialogue, 2007, Cilt 38, No 3, ss. 379-402.

GEORGİS, Mariam and Nicole V.T. Lugosi, "(Re)inserting race and indigeneity in international relations theory: a post-colonial approach", Global Change, Peace \& Security, 2013, Cilt 26, No 1, ss.71-83. 
Uluslararası İlişkiler ve Uluslararası Göç Bağlamında İnsan Ticareti

LACZKO, Frank, "Introduction, Data and Research on Human Trafficking: A Global Survey", International Migration, 2005, Cilt 43, No 1/2, ss. 5-16.

LOBASZ, Jennifer K., "Beyond Border Security: Feminist Approaches to Human Trafficking", Security Studies, 2013, Cilt 18, No 2, ss. 319-344.

MAKEİ, Vladimir, "Human Trafficking in the Post-Cold War Period: Towards a More Comprehensive Approach", Columbia University Journal of International Affairs, 2013, http://jia.sipa.columbia.edu/ online-articles/human-trafficking-post-cold-war/, (Erişim Tarihi: 01.12.2018).

MCDONALD, Matt, "Human Security and the construction of security", Global Society, 2002, Cilt 16, No 3, ss. 277-295.

MEMIŞ̧OGLU, Fulya, "Between the Legacy of Nation-State and Forces of Globalisation: Turkey's Management of Mixed Migration Flows", EUI RSCAS Working Paper Series, 2014, No 122, http://cadmus.eui.eu/bitstream/handle/ 1814/33862/RSCAS_2014_122.pdf?sequence=1 (Erişim Tarihi: 12.03.2019).

NADİG, Aninia, "Human Smuggling, National Security, and Refugee Protection", Journal of Refugee Studies, 2002, Cilt 15, No 1, ss. 1-25.

OBOKATA, Tom, "Trafficking of Human Beings as a Crime Against Humanity: Some Implications for the International Legal System", The International and Comparative Law Quarterly, Cilt 54, No 2, 2005, ss.445-457.

SALT, John, "Trafficking and Human Smuggling: A European Perspective", International Migration, 2000, Cilt 38, No 3, ss. 31- 56.

SKELDON, Ronald, "Trafficking: A Perspective from Asia", International Migration, 2000, Cilt 38, No 3, ss.7-30.

WALT, Stephen M., "The Renaissance of Security Studies", International Studies Quarterly, 1991, Cilt 35, No 2, ss.211-239.

İnternet Kaynakları

Aile Danışmanları Derneği, "The Power of Civil Society to Combat Human Trafficking", 2017, https://ailedanismanlari.org/human-trafficking/the-power-of-civilsociety-to-combat-human-trafficking-project-nongovernmental-organizations-sopstandard-operational-procedures/ (Erişim Tarihi: 01.12.2018)

Birleşmiş Milletler Küresel Göç Mutabakatı (UN Global Compact for Migration), "Global Compact for Safe, Orderly and Regular Migration, Intergovernmentally Negotiated and Agreed Outcome", 2018, https://refugeesmigrants.un.org/sites/ default/files/180711_final_draft_0.pdf (Erişim Tarihi: 01.12.2018).

Birleşmiş Milletler Uluslararası Kalkınma Programı (United Nations Development Programme/UNDP), “2030 Sürdürülebilir Kalkınma Hedefleri”, 2018, http://www.tr.undp. org/content/turkey/tr/home/sustainable-development-goals.html (Erişim Tarihi: 01.12. 2018).

Birleşmiş Milletler Uyuşturucu ve Suç Ofisi (United Nations Office On Drugs and Crime/UNODC), "Human Trafficking", 2018, https://www.unodc.org/unode/ en/human-trafficking/what-is-human-trafficking.html (Erişim Tarihi: 01.12. 2018).

Birleşmiş Milletler Uyuşturucu ve Suç Ofisi (United Nations Office On Drugs and Crime/UNODC), "UN Global Report on Trafficking in Persons 2016", UNODC Publication, Vienna, 2016, https://www.unodc.org/documents/data-and-analysis/glotip/ 


\author{
Fulya MEMIŞOĞLU
}

\section{6}

Güvenlik

Stratejileri

Cilt: 15

Sayı: 30

2016_Global_Report_on_Trafficking_in_Persons.pdf (Erişim Tarihi: 01.12.2018).

EUROPOL, "Migrant Smuggling in the EU", 2016, https://www.europol. europa.eu/publications-documents/migrant-smuggling-in-eu (Erişim Tarihi: 01.12.2018).

Global Alliance Against Traffic in Women (GAATW), "Smuggling and Trafficking: Rights and Intersections", Working Paper Series, 2011, https://ec.europa.eu/anti-trafficking/ sites/antitrafficking/files/smuggling_and_trafficking._rights_and_intersections_1.pdf (Erişim Tarihi: 01.12.2018).

Göç İdaresi Genel Müdürlüğü (GİGM) Resmî İnternet Sayfası, "Göç İstatistikleri: İnsan Ticareti”, http://www.goc.gov.tr/icerik6/insan-ticareti-ile-mucadele_363_378_ 4714_icerik (Erişim Tarihi: 27.12.2018).

Göç İdaresi Genel Müdürlüğü (GIGM), "2017 Türkiye İnsan Ticaretiyle Mücadele Yıllık Raporu”, Göç İdaresi Genel Müdürlüğü, Yayın No 48, Ankara, 2018, http://www.goc.gov.tr/files/files/INSAN-TICARETI-MAGDURLARI-RAPORU2017-mini.pdf (Erişim Tarihi: 01.12.2018).

Healy, Claire, Targeting Vulnerabilities: The Impact of the Syrian War and Refugee Situation on Trafficking in Persons, International Centre for Migration Policy Development (ICMPD), 2015, https://www.icmpd.org/ fileadmin/ICMPD-Website/AntiTrafficking/Targeting_Vulnerabilities_EN_SOFT_.pdf (Erişim Tarihi: 01.12.2018)

International Labour Organization (ILO), "Global Estimates of Modern Slavery: Forced Labour and Forced Marriage", 2017, https://www.ilo.org/ wcmsp5/groups/public/--dgreports/---dcomm/documents/publication/wcms_575479.pdf (Erişim Tarihi: 01.12.2018). International Organization for Migration (IOM), "Missing Migrants Project", 2018, https://missingmigrants.iom.int (Erişim Tarihi: 01.12.2018).

International Organization for Migration (IOM), Human Trafficking: New Directions for Research, International Organization for Migration, 2008, https://www.iom.int/jahia/ webdav/shared/shared/mainsite/ microsites/IDM/workshops/ensuring_protection_070909/ human_trafficking_new_directions_for_research.pdf (Erişim Tarihi: 01.12.2018)

Iselin, Brian ve Adams, Melanie, Distinguishing between Human Trafficking and People Smuggling, UN Office on Drugs and Crime, Regional Centre for East Asia and the Pacific, 2003, https://www.embraceni.org/wp-content/uploads/2006/06/Distinguish ing[1]1.pdf (Erişim Tarihi: 01.12.2018).

Natalie Jesionka, "Human Trafficking: The Myths and the Realities", The Daily Muse, 2019, https://www.themuse.com/advice/human-trafficking-the-myths-and-therealities (Erişim Tarihi: 12.03.2019).

OSCE/ODIHR, "National Referral Mechanisms: Joining Efforts to Protect the Rights of Trafficked Persons, A Practical Handbook", Warsaw, 2004, , https://www.osce.org/odihr/13967?download=true (Erişim Tarihi: 01.12.2018).

Pierce, Sarah, "The Vital Difference Between Human Trafficking and Migrant Smuggling", Open Democracy, 2014, https://www.open democracy.net/beyondslavery/sarah-pierce/vital -difference-between-human-trafficking-and-migrant-smuggling, (Erişim Tarihi: 01.12. 2018). UNICEF, "Harrowing Journeys: Children and youth on the move across the Mediterranean Sea, at risk of trafficking and exploitation", UNICEF ve International Organisation for Migration (IOM) Ortak Raporu, 2017, https://www.unicef.org/ 
Uluslararası İlişkiler ve Uluslararası Göç Bağlamında İnsan Ticareti

publications/index_100621.html (Erişim Tarihi: 01.12.2018).

\section{Uluslararası/ Ulusal Mevzuat}

Birleşmiş Milletler Uyuşturucu ve Suç Ofisi (United Nations Office On Drugs and Crime/UNODC), United Nations Convention Against Transnational Organized Crime and the Protocols Thereto, United Nations Office on Drugs and Crime, 2000.

Birleşmiş Milletler Uyuşturucu ve Suç Ofisi (United Nations Office On Drugs and Crime/UNODC), Sınırış̧an Örgütlü Suçlarla Mücadele Sözleşmesine ek Kara, Deniz ve Hava Yoluyla Göçmen Kaçakçılığına Karşı Protokol, Viyana, Birleşmiş Milletler, Aralık 2000.

Council of Europe, Convention on Action Against Trafficking in Human Beings and Its Explanatory Report, Council of Europe, 2005.

İnsan Ticaretiyle Mücadele ve Mağdurların Korunması Hakkında Yönetmelik, Resmî Gazete No 29656, 2016, http://www.resmi gazete.gov.tr/eskiler/2016/03/201603179.htm (Erişim Tarihi: 01.12.2018).

Türk Ceza Kanunu, Resmî Gazete No 25611, 2004, http://www.mevzuat.gov.tr/Metin1.Aspx?MevzuatKod=1.5.5237\&MevzuatIliski=0\&s ourceXmlSearch $=\&$ Tur $=1 \&$ Tertip $=5 \& \mathrm{No}=5237$ (Erişim Tarihi: 12.03.2019).

Yabancilar ve Uluslararası Koruma Kanunu (YUKK), Resmî Gazete No 28615, 2013, http://www.resmigazete.gov.tr/eskiler/ 2013/04/20130411-2.htm (Erişim Tarihi: 01.12.2018).

Uluslararası İş Gücü Kanunu, Resmî Gazete No 29800, 2016, http://www.mevzuat.gov.tr/MevzuatMetin/1.5.6735.pdf (Erişim Tarihi: 01.12.2018).

Mülakatlar

Mülakat 1, Aralık 2017, Ankara.

Mülakat 2, Aralık 2017, Ankara.

Mülakat 3, Aralık 2017, Ankara.

Mülakat 4, Aralık 2017, Ankara.

Mülakat 5, Aralık 2017, Ankara 